$\mathbf{P}$

\section{PAINTING AND DECORATING CONTRACTORS OF AMERICA (PDCA)}

1801 Park 270 Drive, Suite 220, St Louis, MO, 63146, United States of America

Tel: (1) 8003327322

Fax: (1) 3145149417

Email: ihoren@pdca.org

Website: www.pdca.org

The PDCA was established in 1884 by a group of contractors to devise a means for assuring the public of the skill, honorable reputation, and probity of master painters.

\section{A E Robert Friedman PDCA Scholarship}

Subjects: All subjects.

Purpose: To provide financial assistance for college or graduate school to students who are nominated by a member of the Painting and Decorating Contractors of America.

Eligibility: Open to applicants who are nominated by an active member of the Painting and Decorating Contractors of America. Nominees must be between 18 and 24 years of age and be attending a postsecondary educational institution as an undergraduate or graduate student. Selection is based on character, financial need, and academic record.

Level of Study: Postgraduate

Type: Scholarship

Value: $\$ 1,000$ per year

Frequency: Annual

No. of awards offered: Varies

Application Procedure: See the website.

Closing Date: September 17th

Additional Information: This program was established in 1978.

\section{PALOMA O'SHEA SANTANDER INTERNATIONAL PIANO COMPETITION}

Calle Hernán Cortés 3, Santander, E-39003, Spain

Tel: (34) 942311451

Fax: (34) 942314816

Email: concurso@albeniz.com

Website: www.fundacionalbeniz.com

Contact: A Kaufmann, Secretariat General

The Paloma O'Shea Santander International Piano Competition is one of the best rated competitions in the world. It provides an opportunity for exceptionally talented pianists to enhance their careers. The jury is composed of renowned musicians in order to ensure that grants are made in a fair and unbiased manner.

\section{Paloma O’Shea Santander International Piano \\ Competition}

Subjects: Piano performance.

Purpose: To give support to young pianists of exceptional talent. Eligibility: Open to pianists of any nationality under 29 years of age. Level of Study: Unrestricted

Type: Competition

Value: Approx. US $\$ 135,000$

Length of Study: July 25th to August 7th

Frequency: Every 4 years

Country of Study: Spain

No. of awards offered: 7

Application Procedure: Please refer to the website

www.santanderpianocompetition.com.

Closing Date: November

Funding: Commercial, foundation, government, private

Contributor: Fundacion Albeniz

No. of awards given last year: 7

No. of applicants last year: 220

Additional Information: Please check website for further details.

\section{PAN AMERICAN HEALTH ORGANIZATION (PAHO) REGIONAL OFFICE OF THE WORLD HEALTH ORGANIZATION (WHO)}

Regional Office for the Americas/Pan American Sanitary Bureau, 525 23rd Street NW, Washington, DC, 20037-2895, United States of America Tel: (1) 2029743000 Fax: (1) 2029743663

Email: rgp@paho.org

Website: www.paho.org

Contact: Grants Administrator

The Pan American Health Organization (PAHO) is an international public health agency working to improve the health and living standards of the countries of the Americas. It serves as the specialized organization for health of the Inter-American System and as the regional office for the Americas of the World Health Organization.

\section{PAHO Grants}

Subjects: Public health studies.

Purpose: To contribute to the public health of the countries of the Americas (individual programme objectives vary). Programmes include graduate thesis grants, research training grants, regional research competitions (announced yearly) and special initiatives announced via the PAHO website.

Eligibility: Open to citizens and residents of Latin America and the Caribbean.

Level of Study: Doctorate, Graduate, Postgraduate, Research

Type: Research grant

Value: Please contact the organization

Study Establishment: Varies

Country of Study: Latin America or Caribbean countries only No. of awards offered: Varies according to the programme Application Procedure: Applicants must complete an application form. Guidelines and application forms are available from the website. Closing Date: Varies according to the programme

Funding: Government

Contributor: Member states and their agencies

\section{PARALYZED VETERANS OF AMERICA (PVA)}

801, 18th Street NW, Washington DC, 20006-3517, United States of America Tel: (1) 8005559140 Fax: (1) 2024167652

Email: info@pva.org

Website: www.pva.org

The Paralyzed Veterans of America (PVA), a congressionally chartered veterans service organization founded in 1946, has developed a unique expertise on a wide variety of issues involving the special needs of the members-veterans of the armed forces who have experienced spinal cord injury or dysfunction.

\section{PVA Educational Scholarship Program}

Subjects: Spinal cord injury or dysfunction.

Purpose: To provide financial support for PVA members so that they can achieve their goals in the academic arena.

Eligibility: Open to all PVA members and their families.

Level of Study: Postgraduate

Type: Scholarship

Value: US $\$ 1,000$ to full-time student, US $\$ 500$ to part-time student Frequency: Annual

No. of awards offered: 10

Application Procedure: Details are available on the website.

Closing Date: May 1st

Additional Information: We expect to offer new college scholarships next year. Check back on our website after April 1st, for complete information and a new application form. 


\section{PARAPSYCHOLOGY FOUNDATION, INC.}

PO Box 1562, New York, NY, 100210043

United States of America

Tel: (1) 2126281550

Fax: (1) 2126281559

Email: office@parapsychology.org

Website: www.parapsychology.org

Contact: Vice President

Established in 1951, the Parapsychology Foundation acts as a clearinghouse for information about parapsychology. Essentially an administrative organization, it maintains one of the largest libraries to do with parapsychology, the Eileen J Garret Library, as well as supporting various programmes that include the library, a grant and scholarship programme, a conference and lecture programme, and a speaker's bureau and publishing programme.

\section{Eileen J Garrett Scholarship}

Subjects: Parapsychology.

Purpose: To assist students attending an accredited college or university in pursuing the academic study of the science of parapsychology.

Eligibility: Open to nationals of any country.

Level of Study: Unrestricted

Type: Scholarship

Value: US $\$ 3,000$

Length of Study: 1 year

Frequency: Annual

Study Establishment: An accredited college or university

Country of Study: Any country

No. of awards offered: 1

Application Procedure: Applicants must submit samples of writings on the subject with an application form from the Foundation. Letters of reference are required from three individuals, familiar with the applicant's work and/or studies in parapsychology.

Closing Date: July 15th

For further information contact:

Email: office@parapsychology.org

\section{Parapsychology Foundation Grant}

Subjects: Parapsychology.

Purpose: To support original study, research and experiments in parapsychology.

Eligibility: Open to nationals of any country.

Level of Study: Unrestricted

Type: Grant

Value: Up to US $\$ 3,000$

Length of Study: 1 year

Frequency: Annual

Country of Study: Any country

No. of awards offered: 10

Application Procedure: Applicants must contact the organization for details.

Closing Date: July 15th

Additional Information: Funding for the Foundation Grant is limited but applicants are still welcome to submit a proposal on the off chance that the programme will be reviewed.

\section{PARIS SCHOOL OF INTERNATIONAL AFFAIRS (PSIA)}

\author{
27, rue Saint-Guillaume, Paris, 75007, \\ France
}

Tel: (33) 145495050

Website: www.sciencespo.fr/psia/

In keeping with Sciences Po's centennial tradition of excellence, PSIA offers a cutting-edge education to tomorrow's leaders in international affairs. With 1300 students coming from 100 countries, taught by world-renowned professors and practitioners, PSIA rises as a vibrant global pulse in Europe and a primary platform for global debate, rooted in the academy.

\section{KSP Excellence Scholarship}

Purpose: The Kuwait Program at Sciences Po offers excellence scholarships to students with an interest in the Middle East who are admitted to PSIA for the current year intake on the programs listed at the website.

Eligibility: These scholarships are awarded on a competitive basis, based on the candidate's excellent academic record and proposed project at Sciences Po.

Type: Scholarship

Value: Multiple scholarships of up to $€ 10,000$ per year will be awarded for the 2 years of study

Frequency: Annual

Application Procedure: Please visit www.sciencespo.fr/psia/kuwaitprogram for detailed information.

Additional Information: The Kuwait Program at Sciences Po (KSP) is a partnership between the Kuwait Foundation for the Advancement of Sciences (KFAS) and Sciences Po, based at the Paris School of International Affairs.

\section{PARKER B FRANCIS FELLOWSHIP PROGRAM}

VA Puget Sound Health Care System, 1660S Columbian Way, 151L, Seattle, WA, 98108, United States of America Tel: (1) 2067642219

Fax: (1) 6172772382

Email: deborah.snapp@gmail.com Website: www.francisfellowships.org Contact: Ms Deborah Snapp

A private foundation dedicated to creating current and future generations of well-rounded individuals who are creative, life-long learners, striving to achieve their fullest potential within their communities.

\section{Parker B Francis Fellowship Program}

Subjects: Pulmonary research.

Purpose: To support rising stars in the field of pulmonary research as they make the transition from postdoctoral trainees to independent researchers.

Eligibility: Ideally, open to applicants with between 2 and 7 years of postdoctoral research experience, published articles in leading journals and a clear trajectory in pulmonary research.

Level of Study: Postdoctorate

Type: Fellowship

Value: The total budget is limited to US $\$ 50,000$ for the 1st year, US $\$ 52,000$ for the 2 nd and US $\$ 54,000$ for the 3rd. These totals include a stipend plus fringe benefits and may include travel costs to a maximum of US $\$ 2,000$. Direct research project costs and indirect costs are not covered

Length of Study: 3 years

Frequency: Annual

Country of Study: United States of America, Canada or Mexico No. of awards offered: 15

Application Procedure: Applicants must submit a completed application form, biographical sketch and a brief statement of their career goals. They must also provide a letter from their mentor evaluating the applicant's qualifications and indicating their career goals in the field of pulmonary research, three letters of recommendation, a summary of the past training record of the primary mentor (including names of former trainees and their current positions, sources and level of support with grants pending and the extent of equipment and space for research training available to the primary mentor and trainee) and signatures of the primary mentor, department or division head and the fiscal officer responsible for administering the grant on the face page.

Closing Date: September 16th

Funding: Private

Contributor: The Francis Family Foundation

No. of awards given last year: 15

No. of applicants last year: 69 


\section{PARKINSON'S UK}

215 Vauxhall Bridge Road, London, SW1V 1EJ, England Tel: (44) 02079321332

Fax: (44) 02079639327

Email: researchapplications@parkinsons.org.uk Website: www.parkinsons.org.uk

Contact: Ms Bunia Gorelick, Research Grants Manager

We're the Parkinson's charity that drives better care, treatments and quality of life. Together we can bring forward the day when no one fears Parkinson's.

\section{Clinician Scientist Fellowship}

Purpose: To support MDs and other health professionals studying for a PhD.

Level of Study: Doctorate

Value: Up to $£ 250,000$

Length of Study: 3 years

Frequency: Annual

Country of Study: United Kingdom

Application Procedure: Please see website.

Closing Date: Please see website

\section{Parkinson's UK PhD Studentship}

Subjects: Parkinson's disease.

Purpose: To build research capacity related to Parkinson's by offering fully funded $\mathrm{PhD}$ studentships for outstanding students.

Eligibility: The PhD studentship scheme is not intended to cover funding gaps for $\mathrm{PhD}$ students whose studies have already started. Both home and overseas students with a first degree in a relevant discipline are eligible for this scheme. Supervisors should contact their university's research office regarding fees for overseas students. Applications must be made by potential supervisor who must be based at a UK university, hospital or research institute.

Level of Study: Doctorate

Type: Studentship

Value: A stipend of $£ 16,000$ per year (or $£ 17,000$ per year if in London), full $\mathrm{PhD}$ tuition fees (at the UK/EU rate) and a contribution of up to $£ 10,000$ per year towards research costs. Students from outside of the EU are welcome to apply for this scheme on a full fee paying basis Length of Study: 3 years

Frequency: Annual

Study Establishment: Any UK university, NHS trust, statutory social care organization, or other research institution

Country of Study: United Kingdom

No. of awards offered: Varies

Application Procedure: Applications are made by the potential student's supervisor (who must be based at a UK university, hospital or research institute) through our online system at https://research. parkinsons.org.uk.

Closing Date: Please see website

Funding: Foundation

Contributor: Voluntary donations

No. of awards given last year: 3

No. of applicants last year: 22

\section{Parkinson's UK Project Grant}

Subjects: Parkinson's disease.

Purpose: To support studies designed to answer a single

question or a small group of related questions about an aspect of

Parkinson's.

Eligibility: Grants are tenable only at a UK university or NHS Trust or statutory social care organization. Applicants should hold employment contracts that extend beyond the period of grant.

Level of Study: Research

Type: Project grant

Value: To include at least one salary plus consumables and equipment

Length of Study: Up to 3 years

Study Establishment: U.K. university, NHS trust, statutory social care organization or other research institution

Country of Study: United Kingdom

No. of awards offered: Varies

Application Procedure: Applicants must complete an online application form available at https://research.parkinsons.org.uk.
Closing Date: Please see website

Funding: Foundation

Contributor: Voluntary donations

No. of awards given last year: 7

No. of applicants last year: 29

Additional Information: For further details visit the charity's website.

\section{Parkinson's UK Senior Research Fellowship}

Subjects: Parkinson's disease.

Purpose: To support researchers looking to make the transition to independence.

Eligibility: Grants are tenable only at a UK university, NHS trust, statutory social care organization or other research institution. Senior: applicants should have a PhD/DPhil and at least 3 years and no more than 6 years postdoctoral experience at time of application deadline. Training: applicants should be aiming to obtain a PhD, MPhil or MD. Level of Study: Research

Type: Fellowship

Value: Up to $£ 250,000$

Length of Study: 3 years

Frequency: Annual

Study Establishment: UK university, NHS trust, statutory social care organization or other research institution

Country of Study: United Kingdom

No. of awards offered: Varies

Application Procedure: Applications are made through our online system at https://research.parkinsons.org.uk.

Closing Date: Please see website

Funding: Government, foundation

Contributor: Voluntary donations

No. of awards given last year: 2

No. of applicants last year: 9

\section{Parkinson's UK Small Grants}

Subjects: Parkinson's disease.

Purpose: Small and flexible grant scheme for researchers working in every field of Parkinson's research.

Eligibility: Principal applicants should hold employment contracts that extend beyond the period of the grant.

Level of Study: Research

Type: Grant

Value: $£ 50,000$

Length of Study: Up to 24 months

Study Establishment: UK university, NHS trust, statutory social care organization or other research institution

Country of Study: United Kingdom

No. of awards offered: Varies

Application Procedure: Applications are made through our online system at https://research.parkinsons.org.uk.

Closing Date: Please see website

Funding: Foundation

Contributor: Voluntary donations

No. of awards given last year: 6

No. of applicants last year: 45

\section{PASTEUR FOUNDATION}

420 Lexington Avenue, Suite 1654, New York, NY, 10170, United States of America Tel: (1) 2125992050

Fax: (1) 2125992047

Email: PasteurUS@aol.com

Website: www.pasteurfoundation.org

Contact: Caitlin Hawke, Executive Director

Pasteur Foundation is located in New York city and works to introduce the research conducted at the Institut Pasteur to the American public, to develop exchanges between Pasteurian and U.S. scientists and to raise funds for Pasteurian research.

\section{Pasteur Foundation Postdoctoral Fellowship Program \\ Subjects: Biomedical science.}

Purpose: To provide financial assistance and develop international scientific exchanges.

Level of Study: Postdoctorate 
Type: Fellowship

Value: US $\$ 70,000$ per year

Length of Study: 3 years

Frequency: Annual

Country of Study: France

Application Procedure: Applicants must submit a passport-size photo, reprints of publications, letters of recommendation, letter of support and curriculum vitae. See fellowship program on www. pasteurfoundation.org.

Closing Date: September

For further information contact:

Institut Pasteur, 25 rue du Docteur Roux, 75724 Paris Cedex 15, France

Contact: Dr Claude Parsot, Secrétariat de la Direction de l'Evaluation Scientifique

\section{THE PAUL \& DAISY SOROS FELLOWSHIPS FOR NEW AMERICANS}

224 West 57th St, New York, NY, 10019, United States of America Tel: (1) 2125476926

Fax: (1) 2125484623

Email: pdsoros_fellows@sorosny.org

Website: www.pdsoros.org

The Soros Foundation was founded by Hungarian immigrants and American philanthropists in December 1997 with a charitable trust of $\$ 50,000,000$ dollars. Their reasons for doing so were several. They wished to give back to the country that had afforded them and their children such great opportunities and felt a fellowship programme was an appropriate vehicle.

\section{Paul and Daisy Soros Fellowships for New Americans}

Subjects: Engineering, medicine, law, social work, humanities, social sciences, sciences, fine arts and performing arts.

Purpose: To provide opportunities for continuing generations of able and accomplished New Americans to achieve leadership in their chosen fields.

Eligibility: Open to immigrants, who have been naturalized as citizens of US or whose parents are both naturalized citizens. Applicants must either have a Bachelor's degree or be in their final year of undergraduate study and must not be older than 30 years of age as of November 1 st.

Level of Study: Doctorate, Graduate, Postgraduate

Type: Fellowships

Value: US $\$ 25,000$ (paid in two installments) and a tuition grant of onehalf the tuition cost of the US graduate programme attended by the Fellow (up to $\$ 20,000$ per academic year)

Length of Study: 2 years

Frequency: Annual

Study Establishment: Any accredited graduate programme

Country of Study: United States of America

Application Procedure: Applicants must submit a completed online application form, 2 essays on specified topics, curriculum vitae of 1-2 pages, 3 recommendation letters, transcripts and provide a photocopy of the test scores of Graduate Management Admission Test, MCAT, Graduate Record Examination and LSAT.

Closing Date: November 1st

Funding: Trusts

No. of awards given last year: 30

No. of applicants last year: 890

Additional Information: Individuals are expected to retain loyalty and a sense of commitment to their country of origin as well as to the US, but it is intended to support individuals who will continue to regard the US as their principal residence and focus of national identity.

\section{The Paul \& Daisy Soros Fellowship for New Americans}

Subjects: All subjects.

Purpose: To provide opportunities for continuing generations of able and accomplished New Americans to achieve leadership in their chosen fields.

Eligibility: Open to New Americans: immigrants (Green Card Holders) naturalized US citizens and/or children of 2 naturalized parents.
Level of Study: Postdoctorate

Type: Fellowship

Value: US $\$ 25,000$ up to $\$ 20,000$ in tuition support for each year Length of Study: 2 years

Study Establishment: Any accredited graduate University in the US

Country of Study: United States of America

Application Procedure: Apply online.

Closing Date: November 12th

Funding: Private

Contributor: Paul and Daisy Soros

No. of awards given last year: 30

No. of applicants last year: 77

\section{THE PAUL FOUNDATION}

Apeejay House, 15 Park Street, Kolkata, West Bengal, 700 016, India Tel: (91) 03344035455

Fax: (91) 03322299596

Email: thepaulfoundation@apeejaygroup.com

Website: www.thepaulfoundation.org

The Paul Foundation has been conceived to promote the individuals quest for intellectual excellence. To pursue higher studies in India and abroad, the Foundation supports those Indians who have shown ability in their specific areas of interest, to give them an opportunity to develop their potential and be recognized as leaders.

\section{The Paul Foundation Postgraduate Scholarship}

Subjects: Humanities, social sciences, basic sciences, applied sciences, law, management, medicine, engineering, fine arts, and the performing arts.

Purpose: To encourage outstanding scholars who have the ability to produce thoughtful and thought-provoking work and make a difference to society.

Eligibility: Open to applicants who are Indian citizens and have completed their graduation from a UGC-recognized Indian university. Level of Study: Doctorate, Postgraduate

Type: Scholarship

Value: To cover academic, living, and travel expenses for a maximum of 2 years

Frequency: Annual

Country of Study: Any country

Application Procedure: A completed application form must be submitted.

Closing Date: February 28th

Funding: Foundation

\section{THE PAULO CELLO COMPETITION}

PL 1105, Helsinki, FIN-00101, Finland Tel: (358) 405467079

Email: cello@paulo.fi

Website: www.cellocompetitionpaulo.org Contact: Administrative Assistant

The Paulo Cello Competition organizes an international competition for cellists of all nations.

\section{International Paulo Cello Competition}

Subjects: Cello performance.

Eligibility: Open to cellists between 16 and 33 years of age.

Level of Study: Unrestricted

Type: Competition

Value: The 1st prize is $€ 15,000$, the 2 nd prize is $€ 9,000$, the 3 rd prize is $€ 5,000$ and the 4 th prize $€ 2,000$, Special prizes are $€ 1,000$

Frequency: Every 5 years

Country of Study: Finland

No. of awards offered: 6

Application Procedure: Applicants must write for a brochure, which contains details of the application and audition pieces.

Funding: Private

Contributor: The Paulo Foundation

No. of awards given last year: 6

No. of applicants last year: 77 


\section{PEMBROKE CENTER}

172 Meeting Street Box 1958, Brown University, Providence, RI, 02912, United States of America Tel: (1) $4018632643 / 3466$ Fax: (1) 4018631298

Email: pembroke_center@Brown.edu

Website: www.pembrokecenter.org Contact: Director

The Pembroke Center at Brown University is an interdisciplinary research center that fosters critical scholarship on questions of gender and difference, broadly defined, in national and transnational contexts.

\section{Pembroke Center Postdoctoral Fellowships}

Subjects: All subjects.

Purpose: To encourage scholars to pursue research in any discipline. Eligibility: Open to scholars from all disciplines. Recipients may not hold a tenured position.

Level of Study: Postdoctorate

Type: Fellowships

Value: US $\$ 50,000$ plus supplement for health insurance

Length of Study: 1 year

Frequency: Annual

Study Establishment: Brown University

Country of Study: United States of America

No. of awards offered: 3

Application Procedure: Apply online at www.Interfolio.com. See www.pembrokecenter.org for direct link.

Closing Date: December

No. of awards given last year: 3

Additional Information: The Center particularly encourages underrepresented and minority scholars to apply.

\section{PEN AMERICAN CENTER}

\author{
588 Broadway, Suite 303, New York, NY 10012, \\ United States of America \\ Tel: (1) 2123341660 \\ Fax: (1) 2123342181 \\ Email: pen@pen.org, awards@pen.org \\ Website: www.pen.org \\ Contact: Paul W Morris, Awards Director
}

PEN American Center is a fellowship of writers dedicated to advance literature, defend free expression and foster international fellowship. The American Center is the largest of 145 international PEN centers worldwide.

\section{The PEN Translation Fund Grants}

Subjects: Translations of works of fiction, creative nonfiction, poetry, and drama.

Purpose: The fund seeks to encourage translators to undertake projects they might not otherwise have had the means to attempt.

Eligibility: Book-length works that have not previously appeared in English in print or have appeared only in an outdated or flawed translation.

Level of Study: Unrestricted

Type: Grant

Value: US $\$ 2,000-4,000$

Frequency: Annual

Country of Study: Any country

Application Procedure: All applications must include the cover sheet and items outlined at www.pen.org/awards, including the original and translated word, translator curriculum vitae, and artist's statement.

Please send seven copies as instructed.

Closing Date: Between October 1st and February 1st (Early

applications are strongly recommended)

Funding: Private

No. of awards given last year: 11

No. of applicants last year: 140

Additional Information: Anthologies with multiple translators, works of literary criticism and scholarly or technical texts do not qualify.
Translators awarded grants by the fund are ineligible to reapply for 3 years after the year they receive a grant. Please check the website for more details.

For further information contact:

PEN Literary Awards, PEN Translation Fund, PEN American Center Email: awards@pen.org

Website: www.pen.org/awards

\section{PEN Writer's Emergency Fund}

Subjects: Professional writers in acute, emergency financial crisis. Purpose: To assist professional published writers facing emergency situations.

Eligibility: Open to published professional writers and produced playwrights who have a traceable record of writing and publication. Level of Study: Unrestricted

Type: Grant

Value: Up to US $\$ 2,000$

Frequency: Dependent on funds available

Application Procedure: Applicants must submit an application consisting of a two-page form, published writing samples, documentation of financial emergency, including bills, etc. and a professional curriculum vitae.

Closing Date: March 15th

Funding: Private

No. of awards given last year: 40

Additional Information: A separate fund exists for writers and editors with AIDS who are in need of emergency assistance. The funds are not for research purposes, to enable writers to complete unfinished projects, or to fund writing publications or organizations. Grants and loans are for unexpected emergencies only, for the support of working writers. PEN American Center also offers numerous annual awards to published writers to recognize distinguished writing, editing and translation.

\section{PENINSULA SCHOOL OF MEDICINE AND DENTISTRY}

The John Bull Building, Tamar Science Park, Research Way, Plymouth, PL6 8BU, England Tel: (44) 01752437474 Fax: (44) 01752517842 Email: info@psmd.ac.uk Website: www.pcmd.ac.uk

Peninsula Medical School and Peninsula Dental School have come together in The Peninsula College of Medicine and Dentistry, a partnership with the University of Exeter, University of Plymouth and the NHS in Devon and Cornwall. The Peninsula Medical School was established in 2000 and Peninsula Dental School was established in 2006. Postgraduate study, either at Masters level through taught programmes, or Doctorate level through research is available through the Peninsula College of Medicine \& Dentistry Graduate School.

\section{Peninsula College of Medicine and Dentistry PhD Studentships}

Purpose: To attract $\mathrm{PhD}$ candidates of outstanding ability to join their exciting and rapidly expanding programme of internationally rated research.

Eligibility: Open to the suitably qualified graduates.

Level of Study: Doctorate

Type: Studentship

Value: $£ 13,290$ (Research Council Rate)

Frequency: Dependent on funds available

Study Establishment: Peninsula College of Medicine \& Dentistry

Country of Study: England

Application Procedure: Check website for the details.

Closing Date: November 8th (See the details of specific studentship on website)

Contributor: Various sources 


\section{PENN ARTS \& SCIENCES}

University of Pennsylvania, 3451 Walnut Street, Philadelphia, PA, 19104, United States of America Tel: (1) 2158985000

Fax: (1) 2157465946

Email: humanities@sas.upenn.edu

Website: www.humanities.sas.upenn.edu

The Penn Humanities Forum promotes interdisciplinary collaboration across University of Pennsylvania departments and schools and between the University and the Philadelphia region. Each year, a broad topic sets the theme for a research seminar for resident and visiting scholars, courses and public events involving Philadelphia's cultural institutions.

\section{Mellon Postdoctoral Fellowships in the Humanities Subjects: Humanities.}

Purpose: To support research by untenured junior scholars. Eligibility: Open to junior scholars who, at the time of application, have received a PhD (degree must be in hand no later than December of the year preceding the fellowship) but have not held it for more than 8 years nor been granted tenure. Applicants may not be tenured during the year of the fellowship. Research proposals must relate to the Forum's annual topic of study and are invited in all areas of humanistic studies, except educational curriculum-building and the performing arts. Other requirements include residency at the University of Pennsylvania and the teaching of one freshman seminar in each of the two semesters.

Level of Study: Postdoctorate

Type: Fellowship

Value: The initial stipend is $\$ 61,060$ with an additional $\$ 2,000$ available for research and travel expenses. Health insurance and a one-time moving allowance of $\$ 2,000$ are also provided

Length of Study: 1 academic year, non-renewable Frequency: Annual

Study Establishment: The University of Pennsylvania

Country of Study: United States of America

No. of awards offered: 5

Application Procedure: Applicants must complete an application form, which can be downloaded from the Forum's website.

Closing Date: November 12th

Funding: Foundation

No. of awards given last year: 5

No. of applicants last year: 200

Additional Information: Fellows may not normally hold other awards concurrently.

\section{PERKINS SCHOOL OF THEOLOGY}

Southern Methodist University, PO Box 750133, Dallas, TX, 75275 0133, United States of America

Tel: (1) 2147688436

Fax: (1) 2147682293

Email: theology@smu.edu

Website: www.smu.edu/perkins

Perkins School of Theology is one of the 13 seminaries of The United Methodist Church (and one of the only 5 university-related United Methodist theological schools), located in the heart of Dallas, Texas, with extension programmes in Houston/Galveston and San Antonio.

\section{Diaconia Graduate Fellowships}

Subjects: Theology.

Purpose: To supplement the financial resources of United Methodist students.

Eligibility: Open to consecrated diaconal ministers or ordained deacons and full-time Doctoral students.

Level of Study: Doctorate

Type: Fellowships

Value: US $\$ 10,000$

Frequency: Annual

Application Procedure: Request for application forms can be sent to theology@smu.edu.

Closing Date: February 1st
Contributor: Section of Deacons and Diaconal Ministries, General Board of Higher Education and Ministry, The United Methodist Church

\section{For further information contact:}

Diaconia Graduate Fellowships Section of Deacons and Diaconal Ministries PO Box 340007, Nashville, TN, 37203-0007

Tel: 6153407375

Email: www.sddm@gbhem.org

\section{THE PERRY FOUNDATION}

16 Sandgate Lane, Wandsworth Common, London, SW18 3JP, United Kingdom

Tel: (44) 02088741460

Email: perry.gbennett@gmail.com

Website: www.perryfoundation.co.uk

Contact: Gordon Bennett, Comaony Secretary

The Perry Foundation offers research awards and postgraduate scholarships in agriculture and related disciplines. Research awards are offered to universities and institutes in the UK and are normally for a 3-year period. Postgraduate scholarships are offered to holders of First or Second Class Degrees and are for a 3-year period leading to a PhD. Both research awards and postgraduate scholarships must be undertaken at a university, college or research establishment in the UK.

\section{Perry Postgraduate Scholarships}

Subjects: The production and utilization of crops for food and nonfood uses, ecologically acceptable and sustainable farming systems, including, in particular, water and nutrient balances, integrated disease and pest control systems for both crops and livestock, socioeconomic studies in the occupation and use of land, the rural economy and infrastructure and developments in marketing. Projects must be of definable benefit to UK agriculture.

Purpose: To enable postgraduates undertake research and investigative work in agriculture and related fields and to build up a pool of highly competent researchers in the UK.

Eligibility: Applicants must hold a First or Upper Second Class (Honours) Degrees in appropriate subjects, and must have been offered a place at a university, college or other establishment in the UK that will lead to the award of a PhD.

Level of Study: Doctorate

Type: Postgraduate scholarships

Value: UK£12,000 contribution per year

Length of Study: 3-4 years

Frequency: Annual

Study Establishment: Universities, colleges, research establishments and institutes in the UK

Country of Study: United Kingdom

No. of awards offered: $2-4$ per year

Application Procedure: Applicants must write to or email the Foundation Secretary for an application form. Full details will be provided to suitable applicants.

Closing Date: October 31st

Funding: Foundation

No. of awards given last year: 3

No. of applicants last year: $100+$

Additional Information: Projects must be of definable benefit to U.K. agriculture.

\section{Perry Research Awards}

Subjects: The production and utilization of crops for food and nonfood uses, ecologically acceptable and sustainable farming systems, including, in particular, water and nutrient balances, integrated

disease and pest control systems for both crops and livestock, socioeconomic studies in the occupation and use of land, the rural economy and infrastructure and developments in marketing. Must be of definable benefit to UK agriculture.

Purpose: To support research projects at research establishments, universities and colleges in the UK and investigative work into agriculture and related fields.

Eligibility: Open to universities, colleges and research establishments in the UK.

Level of Study: Research

Type: Research award 
Value: Research awards are normally UK£15,000 per year maximum Length of Study: Normally 3 years

Frequency: Annual

Study Establishment: Universities, colleges, institutes and research establishments

\section{Country of Study: United Kingdom}

No. of awards offered: $2-3$, depending on the availability of funds Application Procedure: Applicants must write to the Foundation Secretary for a brochure, which contains details of the application procedure and application forms. Applications submitted by individuals must be supported by their university, college, institute or other establishment.

Closing Date: October 31st

Funding: Private

No. of awards given last year: 1

No. of applicants last year: $20+$

Additional Information: The research awards must be of definable benefit to U.K. agriculture. Please check website for more details.

\section{PETRO JACYK CENTRAL \& EAST EUROPEAN RESOURCE CENTRE (PJRC)}

\author{
University of Toronto, 130 St. George St., Toronto, \\ ON, M5S 1A5, Canada \\ Email: jacyk.program@utoronto.ca \\ Contact: Petro Jacyk Program for the Study of Ukraine
}

The PJRC supports the activities of the centre for European, Russian and Eurasian studies, the Department of Slavic Languages and Literatures and the 5 research chairs connected with Estonian, Finnish, Hungarian, Polish History and Ukranian studies.

\section{Petro Jacyk Program}

Subjects: Social sciences and humanities.

Purpose: The objective of the Post-Doctoral Fellowship is to support annually one of the most promising junior scholars studying contemporary Ukraine and thereby to advance academic understanding of Ukrainian politics, culture, and society.

Eligibility: The Petro Jacyk Post-Doctoral Fellowship is available to junior scholars in the social sciences and humanities with a research and teaching focus on contemporary Ukraine. The fellowship is open to recently awarded $\mathrm{PhDs}$ (persons holding doctorates for no more than three years at the time of application)

Level of Study: Postdoctorate

Type: Fellowship

Value: CAD $\$ 40,000$, which includes payment for teaching a semester-long course, and separately an allowance of up to CAD $\$ 2,500$ for research and travel expenses

Length of Study: 1 year

Study Establishment: University of Toronto

Country of Study: Canada

No. of awards offered: 1

Application Procedure: Please send applications by email to: the Foundation at pjef@bellnet.ca and the Petro Jacyk Program for the Study of Ukraine at the University of Toronto at jacyk. program@utoronto.ca simultaneously.

Closing Date: February 1st

Contributor: Petro Jacyk Education Foundation

Additional Information: For more information on the post-doctoral fellowship, please visit our website. http://sites.utoronto.ca/jacyk/ postdoctoral fellowship/call for applications.htm.

\section{PFIZER INC.}

Pfizer MAP Program, MedPoint Communications, 1603 Orrington Ave, Suite 1900, Evanston, IL, 60201, United States of America

$$
\begin{aligned}
& \text { Tel: (1) } 8772546953 \\
& \text { Fax: (1) } 8474257028
\end{aligned}
$$

Email: MAPinfo@clinicalconnexion.com

Website: www.pfizermap.com

Contact: MAP Program Coordinator

As a reflection of our commitment to the advancement of healthcare, Pfizer Inc. is pleased to support medical innovation in a wide range of discipline through our Medical and Academic Partnership (MAP) grants and awards. Our Fellowships and Scholar Grants, which offer career-building opportunities for academic researchers in basic, outcomes, and patient-oriented research, are key among these efforts. In addition, Pfizer Visiting Professorships continue to be a resource for in-depth, clinically focused exchange between medical scholars, host organizations and outside scholar-scientists. At Pfizer, we are proud to support the innovators and ideas that help make better treatments and cures possible.

\section{ACCF/Pfizer Visiting Professorships in Cardiovascular Medicine}

Subjects: Medicine

Purpose: To provide opportunities for academic institutions to host a recognized expert for three days of educational exchange.

Eligibility: Open to US medical schools and/or teaching hospitals.

Level of Study: Professional development

Type: Grant

Value: US $\$ 7,500$

Length of Study: 3 days

Frequency: Annual

Country of Study: United States of America

No. of awards offered: 8

Application Procedure: See the website.

Closing Date: January 27th

Funding: Corporation

Contributor: The American College of Cardiology Foundation

(ACCF) and Pfizer Inc.

Additional Information: Please check website for more details.

\section{AUAER/Pfizer Visiting Professorships in Urology}

Subjects: Medicine.

Purpose: To provide opportunities for academic institutions to host a recognized expert for 3 days of educational exchange.

Eligibility: Open to US medical schools and/or teaching hospitals.

Level of Study: Postgraduate, Professional development

Type: Grant

Value: US $\$ 7,500$

Frequency: Annual

Country of Study: United States of America

No. of awards offered: Up to 4

Application Procedure: See the website.

Closing Date: February 12th

Funding: Corporation

Contributor: The American Urological Association Education and

Research Inc.

Additional Information: Please see website.

\section{Pfizer Atorvastatin Research Awards Program}

Subjects: Medicine.

Purpose: To support outstanding investigators at the early stages of their careers in academic research

Eligibility: Open to US citizens who hold an MD or PhD

Level of Study: Research

Type: Grant

Value: US $\$ 50,000$ per year

Length of Study: 2 years

Frequency: Annual

No. of awards offered: 20

Application Procedure: A proposal must be submitted. See the website for further information.

Closing Date: March 17th

Funding: Corporation

For further information contact:

208 East 51st Street, PBM 173, New York, NY, 10022-6501, United States of America

\section{Pfizer Fellowship in Biological Psychiatry}

Subjects: Biological psychiatry.

Purpose: To provide training opportunities for promoting young

physicians who wish to pursue research in an academic environment.

Eligibility: Open to applicants who are the citizens of the US.

Level of Study: Postdoctorate

Type: Grant

Value: US $\$ 65,000$ per year 
Length of Study: 3 years

Frequency: Annual

Application Procedure: A complete form must be submitted.

Closing Date: January 10th

Additional Information: Please check website for more details.

For further information contact:

UF college of medicine, 392-5398, United States of America Contact: Dr Kristen Madsen, Director, Grants Programme Development

\section{Pfizer Fellowships in Health Literary/Clear Health \\ Communication}

Subjects: Medicine, health administration.

Purpose: To fund scientific research in health literary/clear health communication.

Eligibility: Open to U.S. citizens who have undergone at least 1 year of postdoctoral clinical training.

Level of Study: Professional development, Doctorate

Type: Fellowship

Value: Up to $\$ 100,000$, paid over 2 years at $\$ 50,000$ per year

Length of Study: 2 years

Frequency: Annual

No. of awards offered: 1

Application Procedure: See the website.

Closing Date: February 11th

Funding: Corporation

Additional Information: Please check website for more details.

\section{Pfizer Fellowships in Public Health Overview}

Subjects: Health administration.

Purpose: To support the career development of faculty

Eligibility: Open to U.S. citizens who demonstrate that at least 75 per cent their professional time will be devoted to research.

Level of Study: Postgraduate, Professional development

Type: Grant

Value: Up to $\$ 100,000$, paid over 2 years at $\$ 50,000$ per year

Length of Study: 2 years

Frequency: Annual

No. of awards offered: Up to 2

Application Procedure: See the website.

Closing Date: February 10th

Additional Information: Please check website for more details.

The Pfizer Fellowships in Rheumatology/Immunology

Subjects: Rheumatology and immunology.

Purpose: To provide training opportunities for promising young physicians who wish to pursue research in an academic environment. Eligibility: Open to applicants who demonstrate a strong career interest in academic research in rheumatology and immunology.

Level of Study: Postdoctorate, Postgraduate

Type: Fellowship

Value: Up to $\$ 100,000$ each, paid at $\$ 50,000$ over 2 years

Length of Study: 3 years

Frequency: Annual

Application Procedure: See the website.

Closing Date: Please contact the organization for more information.

Funding: Commercial

For further information contact:

VF College of Medicine, 392-5398

Contact: Dr Kristen Madsen, Director, Grants Programme

Development

\section{Pfizer International HDL Research Awards Program}

Subjects: Biology.

Purpose: To support outstanding investigators in the field of HDL biology.

Eligibility: Applicant must hold an MD, a PhD, or the equivalent and hold the rank of instructor or assistant professor at the time of application.

Type: Grant

Value: US $\$ 100,000$ per year

Length of Study: 2 years

Frequency: Annual
Application Procedure: See the website.

Closing Date: See the website

No. of awards given last year: 14

For further information contact:

International HDL Research Awards, 335 W. 16th Street., 4th Floor, New York, NY, 10011, United States of America

Contact: Grants Co-ordinator

\section{Pfizer Visiting Professorship in Neurology}

Subjects: Neurology.

Purpose: To bring new educational value to the institution.

Eligibility: Open to accredited US medical schools and/or affiliated teaching hospitals.

Level of Study: Postgraduate, Professional development

Type: Grant

Value: US $\$ 7,500$ each

Length of Study: 3 days

Frequency: Annual

No. of awards offered: Up to 8

Application Procedure: See the website.

Closing Date: August 16th

Contributor: Pfizer Inc.

\section{Pfizer Visiting Professorships in Diabetes}

Subjects: Endocrinology.

Purpose: To bring new educational value to the institution.

Eligibility: Open to all accredited US medical schools (allopathic or osteopathic).

Level of Study: Postgraduate, Professional development

Type: Grant

Value: US $\$ 7,500$ each

Length of Study: 3 days

Frequency: Annual

No. of awards offered: Up to 4

Application Procedure: See the website.

Closing Date: February 12th

Additional Information: Please check website for more details.

Pfizer Visiting Professorships in Health Literacy

Subjects: Health administration.

Purpose: To facilitate in-depth, educationally focused visits by prominent experts to US healthcare organizations.

Eligibility: Open to US medical schools and/or teaching hospitals.

Level of Study: Professional development

Type: Grant

Value: US $\$ 7,500$ each

Length of Study: 3 days

Frequency: Annual

No. of awards offered: 8

Application Procedure: See the website.

Closing Date: February 12th

Funding: Corporation

Additional Information: Please check the website for more details

\section{Pfizer Visiting Professorships in Oncology}

Subjects: Oncology.

Purpose: To advance oncology.

Eligibility: Open to accredited US Medical schools, teaching hospitals and/or academic or community cancer centers.

Level of Study: Postgraduate, Professional development

Type: Grant

Value: US $\$ 7,500$

Length of Study: 3 days

Frequency: Annual

No. of awards offered: Up to 4

Application Procedure: See the website.

Closing Date: February 12th

Funding: Corporation

Additional Information: Please check website.

Pfizer Visiting Professorships in Pulmonology

Subjects: Pulmonology.

Purpose: To bring new educational value to the institution 
Eligibility: Open to accredited US Medical schools and/or affiliated teaching hospitals.

Level of Study: Postgraduate, Professional development

Type: Grant

Value: US $\$ 7,500$ each

Length of Study: 3 days

Frequency: Annual

No. of awards offered: Up to 4

Application Procedure: See the website.

Closing Date: February 12th

\section{Pfizer Visiting Professorships Program}

Subjects: Medicine.

Purpose: To create opportunities for selected institutions to invite a distinguished expert for three days of teaching

Eligibility: Open to accredited medical schools and/or affiliated teaching hospitals.

Level of Study: Postgraduate

Type: Grant

Value: US $\$ 7,500$ each

Frequency: Annual

No. of awards offered: Up to 8

Application Procedure: Applications available online.

Closing Date: February 12th

\section{PHARMACEUTICAL RESEARCH AND MANUFACTURERS OF AMERICA FOUNDATION (PHRMAF)}

950 F Street, N.W., Suite 300, Washington, DC, 20004, United States of America

Tel: (1) 2025727756

Fax: (1) 2025727799

Email: foundation@phrma.org

Website: www.phrmafoundation.org

Contact: Ms Eileen M McCarron, Executive Director

The Pharmaceutical Research and Manufacturers of America Foundation (PhRMAF) is a non-profit organization, established in 1965 to promote public health through scientific and medical research. It provides funding for research and for the education and training of scientists and physicians who have selected pharmacology, pharmaceutics, toxicology, informatics or health outcomes as a career choice.

\section{PhRMAF Paul Calabresi Medical Student Research Fellowship}

Subjects: Pharmacology, toxicology and clinical pharmacology

Purpose: To support medical/dental students who have substantial interests in research and teaching careers in pharmacology/clinical pharmacology and who are willing to work full time in a specific research effort within a pharmacology or clinical pharmacology unit. Eligibility: A candidate must be enrolled in a US medical/dental school and have finished at least 1 year of the school curriculum. Priority consideration will be given to those candidates who project strong commitments to careers in the field of clinical pharmacology. Applicants must be citizens or permanent residents of the US.

Level of Study: Predoctorate, Graduate, Postgraduate

Type: Fellowship

Value: Up to US $\$ 1,500$ per month

Length of Study: 2 years

Frequency: Annual

Study Establishment: An accredited school of medicine or dentistry Country of Study: United States of America

Application Procedure: Requests for the Paul Calabresi Medical Student Research Fellowship are to be submitted online by the appropriate representative of the school or university.

Closing Date: February 1st

Funding: Private

No. of awards given last year: 2

Additional Information: Research projects involving animal subjects require a statement that the project will follow the guidelines set forth by the NIH Guide for the Care and Use of Laboratory Animals and that the project will be performed, reviewed and approved by a faculty committee of the university. The recipient school is expected to submit an annual report on the disposition of the funds awarded by PhRMAF. A final report is due within 60 days after the conclusion of the grant. These reports must be signed by the recipient's sponsor. Any publications, speeches, presentations and other materials that stem directly from the research supported by this grant must acknowledge the support of PhRMAF. Three reprints of each publication should be forwarded to PhRMAF for further information visit the Foundation's website.

\section{PhRMAF PhRMAF Postdoctoral Fellowships in \\ Pharmaceutics \\ Subjects: Pharmaceutics.}

Purpose: To encourage graduates to continue to develop and refine their pharmaceutics research skills through formal postdoctoral training Eligibility: Open to graduates from $\mathrm{PhD}$ programmes in pharmaceutics. Before an individual is eligible to apply for a PhRMAF award, the applicants must first have a firm commitment from a university in the United States of America. Applicants must be full-time students, and the department's chair is expected to verify the applicant's doctoral candidacy. All applicants must be citizens of the United States of America or permanent residents.

Level of Study: Postdoctorate, Postgraduate

Type: Fellowship

Value: US $\$ 40,000$

Length of Study: 1-2 years

Frequency: Annual

Study Establishment: Schools of pharmacy in the United States of America

Country of Study: United States of America

No. of awards offered: Varies

Application Procedure: Applicants must visit the Foundation's website where detailed application requirements are stated and application forms can be downloaded. Applications must include a research plan written by the applicant, the mentor's research record and a description of how the mentored experience will enhance the applicant's career development in pharmaceutics. Applications are to be submitted online by the appropriate representative of the school or university to the Executive Director at PhRMAF.

Closing Date: September 1st

Funding: Private

Additional Information: Research projects involving animal subjects require a statement that the project will follow the guidelines set forth by the NIH Guide for the Care and Use of Laboratory Animals and that the project will be performed, reviewed and approved by a faculty committee of the university.

\section{PhRMAF Postdoctoral Fellowships in Health Outcomes \\ Research}

Subjects: Health outcomes research, patient-reported outcomes or pharmacoeconomics.

Purpose: To support well-trained graduates from PharmD, MD, and $\mathrm{PhD}$ programmes who seek to further develop and refine their research skills through formal postdoctoral training.

Eligibility: Open to full-time students who are citizens or permanent residents of the US. Applicants must have a firm commitment from a university in the US before applying for a PhRMAF award. The department's chair will be expected to verify the applicant's doctoral candidacy.

Level of Study: Graduate, Postdoctorate, Postgraduate

Type: Fellowship

Value: US $\$ 55,000$ stipend per year

Length of Study: Up to 2 years

Frequency: Annual

Study Establishment: An accredited school of medicine, pharmacy, dentistry, public health, or nursing

Country of Study: United States of America

No. of awards offered: Varies

Application Procedure: Applications must include a research plan written by the applicant, the mentor's research record and a description of how the mentored experience will enhance the applicant's career development in health outcomes research. Applications are to be submitted online by the appropriate representative of the school or university to the Executive Director at PhRMAF. Detailed application requirements are stated on the Foundation's website where applicants can download an application form and read the specific requirements for each award. 
Closing Date: February 1st

Funding: Private

No. of awards given last year: 2

\section{PhRMAF Postdoctoral Fellowships in Informatics}

Subjects: Informatics.

Purpose: To support well-trained graduates from $\mathrm{PhD}$ programmes who seek to further develop and refine their informatics research skills through formal postdoctoral training.

Eligibility: Open to full-time students who are citizens or permanent residents of the US. Applicants must have a firm commitment from a university in the US before applying for a PhRMAF award. The department's chair will be expected to verify the applicant's doctoral candidacy.

Level of Study: Postdoctorate

Type: Fellowship

Value: US $\$ 40,000$ per year

Length of Study: 1-2 years

Frequency: Annual

Country of Study: United States of America

No. of awards offered: Varies

Application Procedure: Applicants must submit an application including a research plan written by the applicant, the mentor's research record and a description of how the mentored experience will enhance the applicant's career development in informatics. Applications are to be submitted online by the appropriate representative of the school or university to the Executive Director of at PhRMAF. Detailed application requirements are stated on the Foundation's website where the applicant can download an application form and read the specific requirements for each award.

Closing Date: September 1st

Funding: Private

Additional Information: Research projects involving animal subjects require a statement that the project will follow the guidelines set forth by the NIH Guide for the Care and Use of Laboratory Animals and that the project will be performed, reviewed and approved by a faculty committee of the university.

\section{PhRMAF Postdoctoral Fellowships in Pharmacology/ Toxicology \\ Subjects: Pharmacology and toxicology.}

Purpose: To facilitate career entry into pharmacology or toxicology at the level of postdoctoral training and to provide funding for recent graduates from $\mathrm{PhD}$ programmes who seek to develop research skills through formal postdoctoral training.

Eligibility: Open to applicants with a firm commitment from a university in the US, prior to applying for a PhRMAF award. Applications must be submitted online by an accredited United States of America school and all applicants must be citizens of the US or permanent residents.

Level of Study: Postdoctorate

Type: Fellowship

Value: US $\$ 40,000$ in stipend support per year for one or two years Length of Study: 1-2 years

Frequency: Annual

Study Establishment: An accredited school of medicine, pharmacy, dentistry or veterinary medicine

Country of Study: United States of America

No. of awards offered: Varies

Application Procedure: Applicants must visit the Foundation's website where detailed application requirements are stated and application forms can be downloaded. Applications must be submitted online by the appropriate representative of the school or university to the Executive Director at PhRMAF. An application must include a research plan written by the applicant, a mentor's research record and a description of how the mentored experience will enhance the applicant's career development on pharmacology or toxicology. Closing Date: September 1st Funding: Private

No. of awards given last year: 2

Additional Information: Research projects involving animal subjects require a statement that the project will follow the guidelines set forth by the NIH Guide for the Care and Use of Laboratory Animals and that the project will be performed, reviewed and approved by a faculty committee of the university.

\section{PhRMAF Predoctoral Fellowships in Health Outcomes} Research

Subjects: Health outcomes research, patient-reported outcomes and pharmacoeconomics.

Purpose: To support a student's PhD doctoral programme after coursework has been completed and the remaining training activity is the student's research project.

Eligibility: Open to applicants who have a firm commitment from a university in the US. Applicants must be full-time students and the department's chair is expected to verify the applicant's doctoral candidacy. All applicants must be citizens of the US or permanent residents.

Level of Study: Postgraduate

Type: Fellowship

Value: A stipend of US $\$ 25,000$ per year, up to US $\$ 1,000$ per year may be used for expenses associated with thesis preparation

Length of Study: 1-2 years

Frequency: Annual

Study Establishment: An accredited school of medicine, pharmacy, dentistry, public health or nursing

Country of Study: United States of America

No. of awards offered: Varies

Application Procedure: Applications are to be submitted online by the appropriate representative of the school or university to the

Executive Director at PhRMAF. Detailed application requirements are stated on the Foundation's website where the applicant can download an application form and read the specific requirements for each award. Closing Date: February 1st

Funding: Private

No. of awards given last year: 2

Additional Information: Research projects involving animal subjects require a statement that the project will follow the guidelines set forth by the NIH Guide for the Care and Use of Laboratory Animals and that the project will be performed, reviewed and approved by a faculty committee of the university.

\section{PhRMAF Predoctoral Fellowships in Pharmaceutics}

Subjects: Pharmaceutics.

Purpose: To support promising students during their thesis research Eligibility: The fellowship programe of predoctoral support is designed to assist full-time, in-residence $\mathrm{PhD}$ candidates in the fields of pharmacology or toxicology who are enrolled in USA schools of medicine, pharmacy, dentistry or veterinary medicine. The programe supports full-time advanced students who will have completed the bulk of their pre-thesis requirements (at least 2 years of study) and are engaged in thesis research as PhD. Please check at http://www. phrmafoundation.org/2015-awards/pre-doctoral-fellowship-awards/ pharmaceutics/ for more information on eligibility.

Level of Study: Postgraduate

Type: Fellowship

Value: A stipend of US $\$ 20,000$ per year, which includes up to

US $\$ 1,000$ for expenses associated with thesis research

Length of Study: 1-2 years

Frequency: Annual

Study Establishment: A school of pharmacy

Country of Study: United States of America

No. of awards offered: Varies

Application Procedure: Applicants must visit the Foundation's website where detailed application requirements are stated and application forms can be downloaded. Applications must be submitted online by the appropriate representative of the school or university to the Executive Director of at PhRMAF.

Closing Date: September 1st

Funding: Private

No. of awards given last year: 6

Additional Information: Research projects involving animal subjects require a statement that the project will follow the guidelines set forth by the NIH Guide for the Care and Use of Laboratory Animals and that the project will be performed, reviewed and approved by a faculty committee of the university.

\section{PhRMAF Predoctoral Fellowships in Pharmacology/ \\ Toxicology}

Subjects: Pharmacology and toxicology.

Purpose: To support promising students during their thesis research. 
Eligibility: Open to advanced students who have completed the bulk of their pre-thesis requirements and are starting their thesis research by the time the award is activated. Students just starting graduate school should not apply. Before an individual is eligible to apply for a PhRMAF award, the applicant must have a firm commitment from a university in the US. The applicant must be a citizen or permanent resident of the US. Please check at http://www.phrmafoundation.org/ 2015-awards/pre-doctoral-fellowship-awards/pharmacology-toxicology/ for more information on eligibility.

Level of Study: Predoctorate

Type: Fellowship

Value: A stipend of US $\$ 20,000$ per year, which includes up to $\$ 1,000$ for expenses associated with thesis research

Length of Study: 1-2 years

Frequency: Annual

Study Establishment: An accredited school of medicine, pharmacy, dentistry or veterinary medicine

Country of Study: United States of America

No. of awards offered: Varies

Application Procedure: Applicants must visit the Foundation's website where detailed application requirements are stated and application forms can be downloaded. Applications must be submitted online by the appropriate representative of the school or university to the Executive Director at PhRMAF

Closing Date: September 1st

Funding: Private

No. of awards given last year: 7

Additional Information: Research projects involving animal subjects require a statement that the project will follow the guidelines set forth by the NIH Guide for the Care and Use of Laboratory Animals and that the project will be performed, reviewed and approved by a faculty committee of the university.

\section{PhRMAF Research Starter Grants in Health Outcomes Research}

Subjects: Health outcomes research, patient-reported outcomes and pharmacoeconomics.

Purpose: To support individuals beginning independent research careers in academia.

Eligibility: Open to applicants sponsored by the school or university at which the research is to be conducted. Applicants must be appointed to an entry level tenure track or equivalent permanent position in a department or unit responsible for pharmaceutical activities as part of its core mission. All applicants must be citizens or permanent residents of the US. Please check at http://www.phrmafoundation.org/2015-awards/pre-doctoralfellowship-awards/health-outcomes/ for more information on eligibility.

Level of Study: Postgraduate, Graduate

Type: Grant

Value: US $\$ 100,000$

Length of Study: 1 year

Frequency: Annual

Study Establishment: An accredited school of medicine, pharmacy, dentistry, public health or nursing

Country of Study: United States of America

No. of awards offered: Varies

Application Procedure: Applicants must visit the Foundations' website where detailed application requirements are stated and application forms can be downloaded. Applications must be submitted online by the appropriate representative of the school or university to the Executive Director of Development at PhRMAF. The description of an applicant's career goals and the departmental chair's description of institutional support for the applicant's salary are all important while evaluating an application

Closing Date: February 1st

Funding: Private

No. of awards given last year: 3

Additional Information: Research projects involving animal subjects require a statement that the project will follow the guidelines set forth by the NIH Guide for the Care and Use of Laboratory Animals and that the project will be performed, reviewed and approved by a faculty committee of the university

\section{PhRMAF Research Starter Grants in Informatics}

Subjects: Informatics

Purpose: To offer support to new investigators beginning their independent research careers in academia at the faculty level.

Eligibility: Open to applicants sponsored by the school or university at which the research is to be conducted. Applicants must be appointed online to an entry level tenure track or equivalent permanent position in a department or unit responsible for informatics activities as part of its core mission. All applicants must be citizens or permanent residents of the US.

Level of Study: Graduate, Postdoctorate, Postgraduate

Type: Grant

Value: US $\$ 100,000$ per year

Length of Study: 1 year

Frequency: Annual

Country of Study: United States of America

No. of awards offered: Varies

Application Procedure: Applicants must visit the Foundation's website where detailed application requirements are stated and application forms can be downloaded. Applications must be submitted online by the appropriate representative of the school or university to the Executive Director at PhRMAF. The description of an applicant's career goals and the departmental chair's description of institutional support for the applicant's salary are all important while evaluating an application.

Closing Date: September 1st

Funding: Private

No. of awards given last year: 5

Additional Information: Research projects involving animal subjects require a statement that the project will follow the guidelines set forth by the NIH Guide for the Care and Use of Laboratory Animals and that the project will be performed, reviewed and approved by a faculty committee of the university.

\section{PhRMAF Research Starter Grants in Pharmaceutics}

Subjects: Pharmaceutics.

Purpose: To offer support to new investigators beginning their independent research careers in academia.

Eligibility: Open to applicants sponsored by the school or university at which the research is to be conducted. Applicants must be appointed to an entry level tenure track or equivalent permanent position in a department or unit responsible for pharmaceutical activities as part of its core mission. All applicants must be citizens or permanent residents of the US.

Level of Study: Postgraduate, Postdoctorate, Graduate

Type: Grant

Value: US $\$ 100,000$ per year

Length of Study: 1 year

Frequency: Annual

Study Establishment: Schools of pharmacy

Country of Study: United States of America

No. of awards offered: Varies

Application Procedure: Applicants must visit the website where detailed application requirements are stated and application forms can be downloaded. Applications must be submitted online by the appropriate representative of the school or university to the Executive Director at PhRMAF. The description of an applicant's career goals and the departmental chair's description of institutional support for the applicant's salary are all important while evaluating an application.

Closing Date: September 1st

Funding: Private

Additional Information: Research projects involving animal subjects require a statement that the project will follow the guidelines set forth by the NIH Guide for the Care and Use of Laboratory Animals and that the project will be performed, reviewed and approved by a faculty committee of the university.

\section{PhRMAF Research Starter Grants in Pharmacology/} Toxicology

Subjects: Pharmacology and toxicology.

Purpose: To support individuals beginning independent research careers in academia.

Eligibility: Open to applicants sponsored by the school or university at which the research is to be conducted. Applicants must be appointed to an entry level tenure track or equivalent permanent 
position in a department or unit responsible for pharmacology or toxicology activities as part of its core mission. All applicants must be citizens or permanent residents of the US.

Level of Study: Postgraduate, Graduate, Postdoctorate

Type: Grant

Value: US $\$ 100,000$ per year

Length of Study: 1 year

Frequency: Annual

Study Establishment: An accredited school of medicine, pharmacy, dentistry or veterinary medicine

Country of Study: United States of America

Application Procedure: Applicants must visit the website where detailed application requirements are stated and application forms can be downloaded. Applications must be submitted online by the appropriate representative of the school or university to the Executive Director of at PhRMAF. The description of an applicant's career goals and the departmental chair's description of institutional support for the applicant's salary are all important while evaluating an application.

Closing Date: September 1st

Funding: Private

No. of awards given last year: 3

Additional Information: Research projects involving animal subjects require a statement that the project will follow the guidelines set forth by the NIH Guide for the Care and Use of Laboratory Animals and that the project will be performed, reviewed and approved by a faculty committee of the university.

\section{PhRMAF Sabbatical Fellowships in Health Outcomes Research}

Subjects: Health outcomes research, patient-reported outcomes and pharmacoeconomics.

Purpose: To support faculty members at all levels with active research programmes and the opportunity to work at other institutions to learn new skills or develop new collaborations that will enhance their research and research training activities in health outcomes.

Eligibility: Open to citizens or permanent residents of the US.

Applicants are expected to have approval for a sabbatical leave from their home institution and to provide an endorsement from the mentor who will sponsor their visiting scientific activity. Matching funds must be provided through the university.

Level of Study: Postdoctorate, Postgraduate, Professional development

Type: Fellowship

Value: A stipend of up to US $\$ 40,000$

Length of Study: 6 months to 1 year

Frequency: Annual

Study Establishment: An accredited school of medicine, pharmacy, dentistry, public health or nursing

Country of Study: United States of America

No. of awards offered: Varies

Application Procedure: Applications are to be submitted online by the appropriate representative of the school or university to the

Executive Director at PhRMAF. Detailed application requirements are stated on the Foundation's website where applicants can download an application form and read the specific requirements for each award.

Closing Date: February 1st

Funding: Private

Additional Information: Research projects involving animal subjects require a statement that the project will follow the guidelines set forth by the NIH Guide for the Care and Use of Laboratory Animals and that the project will be performed, reviewed and approved by a faculty committee of the university.

\section{PhRMAF Sabbatical Fellowships in Informatics}

Subjects: Informatics.

Purpose: To give faculty members at all levels with active research programmes an opportunity to work at other institutions and to develop new collaborations that will enhance their research and research training activities in informatics.

Eligibility: Applicants are expected to have approval for a sabbatical leave from their home institution and provide an endorsement from the mentor who will sponsor their visiting scientific activity. Matching funds must be provided through the university. All applicants must be citizens of the US or permanent residents.
Level of Study: Postgraduate, Postdoctorate, Professional development

Type: Fellowship

Value: Up to US $\$ 40,000$ stipend

Length of Study: 6 months to 1 year

Frequency: Annual

Country of Study: United States of America

No. of awards offered: Varies

Application Procedure: Applications are to be submitted online by the appropriate representative of the school or university to the Executive Director of at PhRMAF. Detailed application requirements are stated on the Foundation's website where the applicant can download an application form and read the specific requirements for each award.

Closing Date: September 1st

Funding: Private

No. of awards given last year: 1

Additional Information: Research projects involving animal subjects require a statement that the project will follow the guidelines set forth by the NIH Guide for the Care and Use of Laboratory Animals and that the project will be performed, reviewed and approved by a faculty committee of the university.

\section{PhRMAF Sabbatical Fellowships in Pharmaceutics}

Subjects: Pharmaceutics.

Purpose: To enable pharmaceutics faculty members at all levels with active research programmes an opportunity to work at other institutions and to develop new collaborations that will enhance their research and research training activities in pharmaceutics.

Eligibility: Open to citizens of the U.S. or permanent residents. Applicants are expected to have approval for a sabbatical leave from their home institution and provide an endorsement from the mentor who will sponsor their sabbatical activity. Matching funds must be provided through the university.

Level of Study: Postgraduate, Professional development,

Postdoctorate

Type: Fellowship

Value: A stipend of up to US $\$ 40,000$

Length of Study: 6 months to 1 year

Frequency: Annual

Study Establishment: An approved institute

Country of Study: United States of America

Application Procedure: Applicants must visit the Foundation's website where detailed application requirements are stated and application forms can be downloaded. Applications must be submitted online by the appropriate representative of the school or university to the Executive Director of at PhRMAF.

Closing Date: September 1st

Funding: Private

Additional Information: Research projects involving animal subjects require a statement that the project will follow the guidelines set forth by the NIH Guide for the Care and Use of Laboratory Animals and that the project will be performed, reviewed and approved by a faculty committee of the university.

\section{PhRMAF Sabbatical Fellowships in Pharmacology/ Toxicology \\ Subjects: Pharmacology and toxicology.}

Purpose: To give faculty members at all levels with active research programmes an opportunity to work at other institutions to learn new skills or develop new collaborations that will enhance their research and research training activities in pharmacology or toxicology. Eligibility: Eligible applicants must (1) hold a PhD degree or appropriate terminal doctorate and record of research accomplishment in a field of study logically or functionally related to the proposed postdoctoral activities, (2) hold a faculty appointment that imparts eligibility for a sabbatical leave from their home institution, (3) have institutional approval of a sabbatical plan that includes partial salary that matches the PhRMA stipend, (4) hold an endorsement from a mentor who agrees to sponsor the applicant's visiting scientist activity, and (5) be a US citizen or permanent resident.

Level of Study: Postdoctorate, Postgraduate, Professional

development

Type: Fellowship

Value: Up to US $\$ 40,000$ stipend

Length of Study: 6 months to 1 year 
Frequency: Annual

Study Establishment: An accredited school of medicine, pharmacy,

dentistry or veterinary medicine

Country of Study: United States of America

No. of awards offered: Varies

Application Procedure: Applicants must visit the Foundation's website where detailed application requirements are stated and application forms can be downloaded. Applications must be submitted online by the appropriate representative of the school or university to the Executive Director of at PhRMAF.

Closing Date: September 1st

Funding: Private

Additional Information: Research projects involving animal subjects require a statement that the project will follow the guidelines set forth by the NIH Guide for the Care and Use of Laboratory Animals and that the project will be performed, reviewed and approved by a faculty committee of the university.

\section{THE PHI BETA KAPPA SOCIETY}

\author{
1606 New Hampshire Avenue NW, Washington, DC, 20009, \\ United States of America \\ Tel: (1) 2022653808 \\ Fax: (1) 2029861601 \\ Email: info@pbk.org \\ Website: www.pbk.org
}

The Phi Beta Kappa Society has pursued its mission of fostering and recognizing excellence in the liberal arts and sciences since 1776.

\section{The Mary Isabel Sibley Fellowship}

Subjects: French language or literature in even-numbered years and Greek language, literature, history or archaeology in odd-numbered years.

Purpose: To recognize female scholars who have demonstrated their ability to carry out original research.

Eligibility: Candidates must be unmarried women 25-35 years of age who have demonstrated their ability to carry out original research. They must hold a doctorate or have fulfilled all the requirements for a doctorate except the dissertation, and they must be planning to devote full-time work to research during the fellowship year. The award is not restricted to members of Phi Beta Kappa or to US citizens.

Level of Study: Doctorate, Postdoctorate, Postgraduate

Type: Fellowship

Value: US $\$ 20,000$

Length of Study: 1 year, non-renewable

Frequency: Annual

Country of Study: Any country

No. of awards offered: 1

Application Procedure: Applicants must complete an application form, available from the website, and submit this with transcripts and references.

Closing Date: January 15th

Funding: Private

No. of awards given last year: 1

No. of applicants last year: 50

For further information contact:

Email: awards@pbk.org

\section{Walter J Jensen Fellowship for French Language, \\ Literature and Culture}

Subjects: French language, literature and culture.

Purpose: To help educators and researchers improve education in Standard French language, literature and culture and in the study of Standard French in the US.

Eligibility: Candidates must be under 40 years of age and must be able to certify their career will involve active use of the French language.

Level of Study: Postgraduate

Type: Fellowship

Value: US $\$ 10,000$, with additional support available for airfare and, if applicable, support of dependants

Length of Study: This 1-year-long fellowship includes 6 months of residence and study

Frequency: Annual
Country of Study: France

No. of awards offered: 1 per year

Application Procedure: Applicants must complete self-managed application form available on the website and submit it along with academic records, references, plans for study and proof of superior competence in French according to the standards established by the American Association for Teachers of French.

Closing Date: January 15th

Funding: Private

Contributor: Dr Walter J Jensen

No. of awards given last year: 1

No. of applicants last year: 15

Additional Information: Preference may be given to, though the eligibility is not restricted to, members of Phi Beta Kappa and teachers at the high school level or above. Standard French is defined to exclude a focus on Creole, Quebecois and other dialects.

\section{PHILHARMONIA ORCHESTRA}

Philharmonia Orchestra, 6th Floor, The Tower Building, 11 York Road, London, SE1 7NX, United Kingdom

Tel: (44) 02079213900

Fax: (44) 02079213950

Email: orchestra@philharmonia.co.uk

Website: www.philharmonia.co.uk

Contact: Mr Martyn Jones, Administrator

\section{Emanual Hurwitz Award for Violinists of British Nationality}

Subjects: Musical performance on violin only.

Purpose: To reward exceptional musical talent.

Eligibility: Open to British nationals only.

Level of Study: Postgraduate

Type: Award

Value: $£ 500$

Frequency: Annual

Country of Study: Any country

No. of awards offered: 1

Application Procedure: Applicants must complete an application form and submit this with a stamped addressed envelope and a nonreturnable registration fee of UK£10.

Closing Date: Check with the website

For further information contact:

Tedward Cottage, Bradcutts Lane, Cookham, Berkshire, SL6 9EW Contact: Jones Martyn, Administrator

\section{John E Mortimer Foundation Awards}

Subjects: Musical performance on all instruments.

Purpose: To reward exceptional musical talent.

Eligibility: Applicants must write for details.

Level of Study: Postgraduate

Type: Award

Value: Prizes of varying value

Frequency: Annual

Country of Study: Any country

No. of awards offered: Varies

Application Procedure: Applicants must complete an application form and submit this with a stamped addressed envelope and a registration fee of UK£15.

Closing Date: December 1st

For further information contact:

Tedward Cottage, Bradcutts Lane, Cookham, Berkshire, SL6 9EW, United Kingdom

Contact: Martyn Jones, Administrator

\section{June Allison Award}

Subjects: Musical performance on woodwind only.

Purpose: To assist exceptional musical talent with specialist and advanced study, and to help bridge the gap between study and fully professional status.

Eligibility: Applicants must write for the details.

Level of Study: Postgraduate

Type: Award 
Value: UK£500 plus recital

Frequency: Annual

Country of Study: Any country

No. of awards offered: 1

Application Procedure: Applicants must complete an application form and submit this with a stamped addressed envelope and a nonreturnable registration fee of UK£10.

Closing Date: December 1st

For further information contact:

Tedward Cottage, Bradcutts Lane, Cookham, Berkshire, SL6 9EW Contact: Martyn Jones, Administrator

\section{Martin Musical Scholarships}

Subjects: Musical performance.

Purpose: To assist exceptional musical talent with specialist and advanced study and to help in bridging the gap between study and fully professional status.

Eligibility: Open to practising musicians as well as students who are instrumental performers, including pianists, preparing for a career on the concert platform either as a soloist or orchestral player, and are of no more than 25 years of age. Preference is given to UK citizens.

Level of Study: Postgraduate

Type: Scholarship

Value: Varies

Length of Study: 2 years, with a possibility of renewal

Frequency: Annual

No. of awards offered: Varies

Application Procedure: Applicants must complete an application form.

Closing Date: Check with the website

Funding: Private

No. of awards given last year: 50

No. of applicants last year: 71

Additional Information: It is not the present policy of the Fund to support organists, singers, conductors, composers, academic students or piano accompanists. Please send your completed application, $£ 20$ application fee, stamped addressed envelope.

For further information contact:

Tedward Cottage, Bradcutts Lane, Cookham, Berkshire, SL6 9EW Contact: Martyn Jones, Administrator

\section{Reginald Conway Memorial Award for String Performers}

Subjects: Musical performance on strings only.

Purpose: To reward exceptional musical talent.

Eligibility: Applicants must write for the details.

Level of Study: Postgraduate

Type: Award

Value: $£ 500$

Frequency: Annual

Country of Study: Any country

No. of awards offered: 1

Application Procedure: Applicants must complete an application form and submit this with a stamped addressed envelope and a nonreturnable registration fee of UK£10.

Closing Date: February 1st

For further information contact:

Tedward Cottage, Bradcutts Lane, Cookham, Berkshire, SL6 9EW Contact: Martyn Jones, Administrator

\section{Sidney Perry Foundation Scholarship}

Subjects: Musical performance.

Purpose: To support postgraduate study.

Eligibility: Open to nationals of any country.

Level of Study: Postgraduate

Type: Scholarship

Value: UK£18,000 (various awards)

Length of Study: Up to 2 years

Frequency: Annual

Country of Study: Any country

No. of awards offered: Varies
Application Procedure: Applicants must complete an application form and submit this with a stamped addressed envelope and a nonreturnable registration fee of UK£10.

Closing Date: February 1st

No. of awards given last year: 3

For further information contact:

Tedward Cottage, Bradcutts Lane, Cookham, Berkshire, SL6 9EW Contact: Martyn Jones, Administrator

\section{PHILLIPS EXETER ACADEMY}

20 Main Street, Exeter, NH, 03833-2460, United States of America Tel: (1) 6037724311

Fax: (1) 6037774384

Email: kcurwen@exeter.edu

Website: www.exeter.edu

Contact: Dr Kathleen Curwen, Dean of Faculty

Phillips Exeter Academy is a private secondary school with over 1,000 students.

\section{George Bennett Fellowship}

Subjects: Creative writing.

Purpose: To allow a person commencing a career as a writer the time and freedom from material considerations to complete a manuscript in progress.

Eligibility: Preference is given to writers who have not published a book with a major commercial publisher. Works must be in English.

Level of Study: Unrestricted

Type: Fellowship

Value: US $\$ 15,260.00$ per year (with housing and meals)

Frequency: Annual

Study Establishment: Phillips Exeter Academy, Exeter, $\mathrm{NH}$

Country of Study: United States of America

No. of awards offered: 1

Application Procedure: Applicants must send a manuscript, together with an application form, personal statement and US\$10.

Closing Date: December 1st for the following academic year

Funding: Private

No. of awards given last year: 1

No. of applicants last year: 150

Additional Information: Duties include being in residence for 1 academic year while working on the manuscript and informal availability to student writers. For further information, please visit the Academy's website.

\section{THE PHILLIPS FOUNDATION}

1 Massachusetts Avenue, NW Suite 620, Washington, DC, 20001, United States of America

Tel: (1) 2022503887 ext 609

Email: jfarley@thephillipsfoundation.org

Website: www.thephillipsfoundation.org

Contact: Vanessa Henderson, Executive Assistant

The Phillips Foundation was founded in 1990. Four years later, we inaugurated our Robert Novak Journalism Fellowship Program to award annual fellowships to young print and online journalists to undertake writing projects supportive of American culture, a free society, and free markets. Our new Fellows are introduced each May at an awards banquet at the National Press Club in Washington, DC before a distinguished audience of journalists, policy leaders and other influential figures.

\section{The Robert Novak Journalism Fellowship Program}

Subjects: Journalism (free market, history and law enforcement).

Purpose: To support working print and online journalists who share the same mission as the Foundation.

Eligibility: Open to US citizens who are working journalists with less than 10 years of professional experience in print and online journalism.

Level of Study: Professional development

Type: Fellowships 
Value: The Novak Fellowship Program offers full-time $\$ 50,000$ fellowships and part-time $\$ 25,000$ fellowships. The full-time fellowships include a $\$ 40,000$ fellowship grant and up to $\$ 10,000$ to reimburse expenses. The part-time fellowships comprise a $\$ 20,000$ grant and up to $\$ 5,000$ for expenses - See more at www.tfas.org Length of Study: 1 year

Frequency: Annual

Country of Study: United States of America

Application Procedure: Applicants can download application forms from the website www.novakfellowships.org.

Closing Date: February 11th

Funding: Private

No. of awards given last year: 7

Additional Information: Apply online at www.novakfellowships.org. Please check website for more details.

\section{THE PIERRE ELLIOTT TRUDEAU FOUNDATION}

600 - 1980 Sherbrooke Street West, Montreal, QC, H3G-1E8, Canada

Tel: (1) 5149380001

Fax: (1) 5149380046

Email: tfinfo@trudeaufoundation.ca

Website: www.trudeaufoundation.ca

Contact: Elise Comtois, Director of Corporate Services and Public Affairs

The Pierre Elliott Trudeau Foundation seeks to promote outstanding research in the social sciences and humanities and to foster a fruitful dialogue between scholars and policymakers in government, business, voluntary sector, professions and the arts community.

Pierre Elliott Trudeau Foundation Doctoral Scholarships

Subjects: Humanities and social sciences.

Eligibility: Open to Canadian citizens, permanent resident of Canada, foreign citizens; full-time first or second year students enrolled (or in the process of enrolling) in a doctoral programe in the humanities and social sciences.

Type: Scholarship

Value: $\$ 40,000$ per year; $\$ 20,000$ per year for research and travel allowance

Length of Study: 3 years

Country of Study: Canada

No. of awards offered: 15

Closing Date: September

Contributor: Pierre Elliott Trudeau Foundation

No. of awards given last year: 15

Additional Information: For more details, please visit the Contact Centre: support@cihr-irsc.gc.ca. Email: competition@trudeaufoundation.ca (general), support@trudeaufoundation.ca (technical questions) Contact: Jose' e St-Martin, Program Director, Doctoral Scholarships

\section{Trudeau Foundation Doctoral Scholarships}

Subjects: Social sciences and humanities.

Purpose: To support doctoral candidates pursuing research of compelling present-day concern in areas touching upon 1 or more of the 4 themes of the Foundation: human rights and social justice, responsible citizenship, Canada and the world, humans and their natural environment. Eligibility: Open to a Trudeau Scholar who is registered full-time in a doctoral level programme approved by the Foundation.

Level of Study: Doctorate

Type: Scholarships

Value: The annual value is up to $\$ 60,000$ per Scholar (including an annual travel allowance of $\$ 20,000$ ) for up to 4 years

Length of Study: 4 years

Frequency: Annual

Country of Study: Canada

Application Procedure: Applications to the Foundation must come from the applicant's academic institution as a result of an internal competition.

Closing Date: December

Funding: Foundation

Contributor: Trudeau Foundation

No. of awards given last year: 15
Additional Information: An additional Canadian $\$ 20,000$ per year will be available to support research-related travel approved by the Foundation, and to cover networking expenses associated with events and joint projects undertaken within the framework of the Foundation's programmes

\section{PLASTIC SURGERY EDUCATIONAL FOUNDATION (PSEF)}

444 East Algonquin Road, Arlington Heights, IL, 60005-4664 United States of America

Tel: (1) 8472289900

Fax: (1) 8007664955

Email: cschmieden@plasticsurgery.org

Website: www.plasticsurgery.org

Contact: Ms Christine Schmieden

The Plastic Surgery Educational Foundation (PSEF) is the research arm of the American Society of Plastic Surgeons (ASPS) with the mission to develop and support domestic and international education, research and public service activities of plastic surgeons.

\section{Pilot Research Grant}

Subjects: Plastic surgery.

Purpose: To promote Plastic Surgery advancement and innovation. These grants provide seed' funding and are intended to allow researchers to conduct preliminary studies related to Plastic Surgery Science.

Eligibility: Open to plastic surgeons and holders of an MD or PhD working in plastic surgery. Residents, Fellows and non-members of ASPS require the sponsorship of a member or candidate of ASPS. Level of Study: Postdoctorate, Postgraduate, Professional development

Type: Grant

Value: Research seed money up to US $\$ 10,000$

Length of Study: 1 year

Frequency: Annual

Country of Study: United States of America or Canada

No. of awards offered: Varies

Application Procedure: Applicants must complete an application available on the website.

Closing Date: December 1st

Funding: Private

Contributor: The Plastic Surgery Educational Foundation

\section{PSEF Scientific Essay Contest}

Subjects: Plastic surgery.

Purpose: To recognize the authors of essays or articles that address timely and important plastic surgery topics. To encourage general understanding of issues impacting the practice of plastic surgery, essays and articles submitted to the Scientific Essay Contest are written to communicate to a broad audience.

Eligibility: Open to persons involved in research in the field of plastic surgery.

Level of Study: Doctorate, Graduate, MBA, Postdoctorate, Postgraduate, Predoctorate, Professional development

Type: Prize

Value: US $\$ 500-3,000$

Frequency: Annual

Country of Study: Any country

No. of awards offered: Varies

Application Procedure: Applicants must submit essays that contain the results of original clinical or basic science research in an area of importance to plastic and reconstructive surgery. Information on essay content and format are available on the website.

Closing Date: Check with the website

Funding: Private

Contributor: Bernard G Sarnat MD, D Ralph Millard Plastic Surgery Society and the Plastic Surgery Educational Foundation

\section{Research Fellowship Grant}

Subjects: Plastic Surgery.

Purpose: To encourage research and academic career development in plastic surgery. The research fellowship is intended to provide supplement salary support during a mentored research experience. 
Eligibility: Open to residents planning to interrupt their training for a research experience or recent residency graduates wishing to supplement their clinical training with a research experience. Residents, Fellows and non-members of the ASPS require the sponsorship of a member or candidate for membership of the ASPS. Level of Study: Postgraduate, Professional development

Type: Grant

Value: Up to US $\$ 50,000$

Length of Study: 1 year

Frequency: Annual

Country of Study: United States of America or Canada

No. of awards offered: Varies

Application Procedure: Applicants must complete an application

available on the website.

Closing Date: Check with the website

Funding: Private

Contributor: PSEF

\section{PLAYMARKET}

PO Box 9767, Te Aro, Wellington, 6141, New Zealand Tel: (64) 43828462

Fax: (64) 43828461

Email: info@playmarket.org.nz

Website: www.playmarket.org.nz

Contact: Director of Playmarket

Playmarket was founded in 1973 to empower New Zealand playwrights and promote their plays. Playmarket offers several playwriting competitions annually and offers agency services, script development and a bookshop.

\section{Adam NZ Play Award}

Subjects: Playwriting.

Eligibility: New Zealand citizen or resident.

Type: Award

Value: New Zealand $\$ 5,000$ for best play, $\$ 1,000$ for best play by a maori playwright, $\$ 1,000$ for best play by a Pasifika playwright; and $\$ 1,000$ for best play by a woman playwright

Frequency: Annual

No. of awards offered: 4

Application Procedure: Open application. Please visit the website for the details.

Closing Date: December 1st

Funding: Foundation

No. of awards given last year: 4

\section{The Bruce Mason Playwriting Award}

Subjects: Playwriting.

Purpose: To recognize achievement at the beginning of a career. Eligibility: New Zealand residents or citizens.

Level of Study: Unrestricted

Type: Award

Value: New Zealand $\$ 10,000$

Length of Study: 1 year

Frequency: Annual

Country of Study: New Zealand

No. of awards offered: 1

Funding: Trusts

No. of awards given last year: 1

No. of applicants last year: Awarded: not by application

\section{PLYMOUTH UNIVERSITY}

Drake Circus, Plymouth, Devon, PL4 8AA, England Tel: (44) 01752600600

Email: prospectus@plymouth.ac.uk Website: www.plymouth.ac.uk

\section{CSCAN International Scholarship}

Subjects: Scholarship is provided in the field of MSc network systems engineering, computer and information security and electrical and electronic engineering offered by the Plymouth University in the UK.
Purpose: The Centre for Security, Communication and Network Research (CSCAN) is offering the scholarship to recognize the academic excellence of international students.

Eligibility: Applicants need not complete an application form for the scholarship because the award is made solely on the basis of previous academic performance on their undergraduate course. Applicants must achieve an IELTS score of 6.5 with a minimum of 5.5 in each element or an equivalent English Language qualification as listed in the English language entry requirements; self-funded student and not in receipt of an official Government, company or any other scholarship; coming to the Plymouth University to join one of the eligible courses; have the required grades or marks from an undergraduate (Bachelor) degree, which is equivalent to a U.K. Honours degree. For detailed information, please check website.

Level of Study: Postgraduate

Type: Scholarship

Value: The scholarships will provide $£ 2,750$

Country of Study: United Kingdom

Application Procedure: Applicants need not complete an application form for the scholarship. Applicants are required to submit the fully completed University Application form.

Closing Date: November 8th

Additional Information: Please contact the university.

\section{International Postgraduate Gaza Scholarships}

Purpose: These scholarships will be awarded on a competitive basis to prospective masters students.

Eligibility: To apply for the scholarship, a student should hold an offer of a place on a masters course at Plymouth University.

Type: Scholarship

Value: Each scholarship will be for a fee discount of $£ 5,000$ on a masters programme at Plymouth University

Country of Study: United Kingdom

No. of awards offered: 2

Application Procedure: Please send completed application form as an attachment to internationalscholarships@plymouth.ac.uk along with a copy of your offer letter; a copy of final transcript/marks sheet from undergraduate degree (if final transcript is not available at the time of application please send the most recent or provisional results); a reference letter, from a suitable source, supporting this scholarship application (please do not supply the same reference as that submitted with the postgraduate application).

Closing Date: June 30th

Additional Information: Please check at http://www1.plymouth.ac. uk/money/support13-14/Pages/international.aspx\#PIS.

\section{International Student Merit Scholarship}

Eligibility: Applicants must have received a conditional offer of a place for a postgraduate taught programme commencing in September and be holding the equivalent of a UK university 1st class

Bachelors degree in a relevant subject.

Type: Scholarship

Value: $£ 2,500$

Country of Study: United Kingdom

No. of awards offered: 10

Application Procedure: Applicants can apply via email. For detailed information, please visit website.

Closing Date: June 30th

Contributor: Plymouth University, UK

Additional Information: Please check at website.

\section{International Student PGT Scholarship}

Purpose: Scholarships are available for international students who wish to study postgraduate taught degree courses.

Eligibility: Applicants should hold a conditional offer of a place on a postgraduate taught degree programme at Plymouth University. The University will automatically consider applicants with relevant Bachelor degree grades as stipulated in the list. Please note this eligibility criteria list is not exhaustive and graduates from all non-EU countries will be considered for these scholarships. The Bachelor's degree must be the equivalent of a UK Honours degree, as specified by UK NARIC. For detailed information, please visit www.plymouth.ac.uk/study/fees/ scholarships-bursaries-and-funding/funding/postgraduate-scholarships-for-international-students. Level of Study: Postgraduate 
Type: Scholarship

Value: $£ 1,500$

Country of Study: United Kingdom

No. of awards offered: 100

Application Procedure: If the student has applied for a postgraduate taught degree programme, they will automatically be considered for this scholarship if their final transcript or marks sheet was submitted with their application.

\section{PhD Studentship at Plymouth University's Marine Institute}

Subjects: Applications are invited for two fully funded international $\mathrm{PhD}$ studentships within Plymouth University's Marine Institute funded by UK Seabed Resources Ltd as part of its training proposal and in line with its contract with the International Seabed Authority (ISA) to explore for potential Polymetallic Nodule collection in the deep Pacific Ocean.

Eligibility: Candidates for the $\mathrm{PhD}$ training programme in polymetallic nodules should hold a degree and master's qualification in a relevant subject such as geology/earth sciences, geochemistry, chemistry, mineralogy or environmental science, or equivalent education acceptable to Plymouth University.

Level of Study: Postgraduate

Country of Study: United Kingdom

No. of awards offered: 2 awards

Closing Date: June 15th

Funding: Trusts

Contributor: Two fully funded international PhD studentships within Plymouth University's Marine Institute funded by UK Seabed

Resources Ltd

\section{Vice Chancellor's International Student Scholarship}

Purpose: The scholarships are available for pursuing Postgraduate degree level at Plymouth University in UK.

Eligibility: Applicants must have received a conditional offer of a place for a postgraduate taught programme commencing in September. Applicants must also be holding the equivalent of a UK university 1 st class Bachelor degree in a relevant subject.

Type: Scholarship

Value: $£ 5,000$

Country of Study: United Kingdom

No. of awards offered: 3

Application Procedure: Please send the application form to internationalscholarships@plymouth.ac.uk. as an attachment along with a copy of offer letter; a copy of final transcript/marks sheet from the applicant's undergraduate degree; a reference letter, from a suitable source, supporting this scholarship application (please do not supply the same reference as that submitted with postgraduate application).

Closing Date: July 31 st

Additional Information: For detailed information, please visit http:// www1.plymouth.ac.uk/money/support13-14/Pages/international. aspx\#PIS.

\section{THE POINT FOUNDATION}

5757 Wilshire Boulevard, Suite 370, Los Angeles, CA, 90036 , United States of America

Tel: (1) 3239331234

Fax: (1) 8663976468

Email: info@pointfoundation.org

Website: www.pointfoundation.org

The Point Foundation provides financial support, mentoring and hope to meritorious students who are marginalized due to sexual orientation, gender expression or gender identity. The Foundation seeks the partnership of philanthropic individuals, corporations and foundations to supply financial support, professional guidance and a network of contacts for undergraduate, graduate and postgraduate students.

\section{The Point Scholarship}

Subjects: All subjects.

Purpose: To support outstanding LGBT students (lesbian, gay, bisexual and transgender) who are underprivileged, especially those who have been abandoned by family and other support systems because of their sexual orientation or gender identity.

Eligibility: Both LGBT and non-LGBT can apply provided they demonstrate leadership, scholastic achievement, participation in extracurricular activities and involvement in the LGBT community. Level of Study: Postgraduate

Type: Scholarship

Value: Average scholarship award per scholar is $\$ 13,600$

Frequency: Annual

Country of Study: United States of America

No. of awards offered: Varies

Application Procedure: Applicants must complete an application online before the stated deadline at www.pointfoundation.org.

Closing Date: February 9th

Funding: Foundation

No. of awards given last year: 27

No. of applicants last year: 1,344

Additional Information: Please check website for more details.

\section{POLLOCK-KRASNER FOUNDATION, INC.}

863 Park Avenue, New York, NY, 10075, United States of America Tel: (1) 2125175400

Fax: (1) 2122882836

Email: grants@pkf.org

Website: www.pkf.org

Contact: Programme Officer

The Pollock-Krasner Foundation's mission is to aid, internationally, those individuals who have worked as professional artists over a significant period of time.

\section{Pollock-Krasner Foundation Grant}

Subjects: Painting, sculpting, print-making, mixed media and installation art.

Purpose: To aid, internationally, individual artists of artistic merit with financial need.

Eligibility: Applicants may be painters, sculptors, print-makers, mixed media or installation artists. The Foundation has no age or geographic limits. Commercial artists, photographers, film-makers, craft-makers and students are not eligible.

Level of Study: Professional development

Type: Grant

Frequency: Annual

Application Procedure: Applicants must write, fax or email to the Foundation for an application and guidelines.

Closing Date: There is no deadline as grants are awarded throughout the year

Funding: Private

Additional Information: The Foundation does not fund academic study. Please check the website for more details.

\section{THE POPULATION COUNCIL}

Policy Research Division, One Dag Hammarskjold Plaza, New York, NY, 10017, United States of America

Tel: (1) 2123390500

Fax: (1) 2127556052

Email: ssfellowship@popcouncil.org

Website: www.popcouncil.org

Contact: Fellowship Co-ordinator

The Population Council is an international non-profit, non-governmental institution that seeks to improve the well being and reproductive health of current and future generations around the world and to help achieve a humane, equitable and sustainable balance between people and resources. The Council conducts biomedical, social science and public health research and helps build research capacities in developing countries.

\section{Biomedical Fellowship Programs}

Subjects: Basic and Translational Reproductive Sciences and HIV/ AIDS Research.

Eligibility: Candidates for pre-doctoral biomedical fellowships must be engaged in graduate study leading to an advanced degree, MD, 
PhD, DVM or equivalent. Candidates for post-doctoral biomedical fellowships must have successfully completed an advanced degree, $\mathrm{MD}, \mathrm{PhD}, \mathrm{DVM}$ or equivalent. If the applicant is other than a US citizen or permanent resident, she/he must have a strong commitment to return to her/his own country.

Level of Study: Predoctorate, Postdoctorate, Professional development, Doctorate

Type: Fellowship

Length of Study: 1-2 years

Frequency: Dependent on funds available

Study Establishment: The Population Council's Centre for Biomedical Research

Country of Study: United States of America

No. of awards offered: Varies

Application Procedure: Contact the Center for Biomedical Research.

Closing Date: No deadline is set. Please check with the website.

For further information contact:

Center for Biomedical Research, 1230 York Avenue, New York, NY 10065

\section{Fred H Bixby Fellowship Program}

Subjects: Population studies in combination with a social science discipline (demography, economics, sociology, anthropology, geography) public health or biomedical sciences.

Purpose: To expand training opportunities by allowing population specialists and biomedical researchers from developing countries to work with experienced mentors in the population Council's international network of offices. Fellowships are awarded to professionals in the early stages of their careers who have demonstrated commitment to return to or stay in a developing country upon completion of their training programs to build capacity in local institutions.

Eligibility: Candidates must have recently completed (within the last 5 years) or anticipate completing a $\mathrm{PhD}$ or equivalent degree in the social sciences, public health or biomedical sciences. All applicants should have previous direct experience with either biomedical research, program research or policy-relevant social science research (preferably including one or more peer-reviewed publications). Applications must be legal citizens of a developing country and be proficient in english.

Level of Study: Postdoctorate, Professional development

Type: Fellowship

Value: A monthly stipend based on Fellowship location and years of experience and attendance at one professional meeting per year (including travel). An allowance for relocation and health insurance are also included

Length of Study: $1-2$ years

Frequency: Annual

Study Establishment: One of the Population Council's international offices

No. of awards offered: Varies

Application Procedure: Applicants must submit an application form, research proposal and supporting documents in English. The application details and procedures can be found on the Bixby Fellowship website www.popcouncil.org/what/bixby.asp. Requests for information from the Fellowship Coordinator, which can be obtained by emailing to bixbyfellowship@popcouncil.org, should include a brief description of the candidate's academic and professional qualifications, a short statement about their research interests for the proposed Fellowship period and their curriculum vitae.

Closing Date: January 31st

Funding: Foundation

Contributor: Fred $\mathrm{H}$ Bixby Foundation

Additional Information: Selection will be based on the recommendation of the Fellowship Committee which consists of distinguished scholars in the field of population. Selection criteria will stress academic excellence, professional experience and prospective contribution to the population field. Prior to submitting a formal application to the Fellowship Office for consideration, Bixby applicants are required to seek sponsorship from at least one Population Council staff mentor, in consultation with the Fellowship coordinator.

\section{PRADER-WILLI SYNDROME ASSOCIATION UK}

125a London Road, Derby, DE1 2QQ, England

Tel: (44) 1332365676

Fax: (44) 1332360401

Email: admin@pwsa.co.uk

Website: http://pwsa.co.uk/

Contact: Administrative Assistant

Prader-Willi Syndrome Association UK provides support and information to people with Prader-Willi Syndrome.

\section{PWSA UK Research Grants}

Subjects: Prader-Willi syndrome.

Purpose: To improve understanding and treatment of Prader-Willi Syndrome.

Level of Study: Unrestricted

Frequency: Dependent on funds available

Country of Study: United Kingdom

Application Procedure: Applicants must write or call the PWSA (UK) for information.

Funding: Private

\section{THE PREHISTORIC SOCIETY}

Institute of Archaeology, University College London, 31-34 Gordon Square, London, WC1H OPY, United Kingdom Fax: (44) 02073832572

Email: prehistoric@ucl.ac.uk

Website: www.prehistoricsociety.org

Contact: Ms Tessa Machling, Administrative Assistant

The Prehistoric Society is open to professionals and amateurs alike and has over 2,000 members worldwide. Its main activities are lectures, study tours and conferences and it publishes an annual journal (PPS) and a newsletter (PAST), which is published 3 times a year.

\section{Prehistoric Society Conference Fund}

Subjects: Archaeology, especially prehistoric.

Purpose: To finance attendance at international conferences. Eligibility: Preference is given first to scholars from developing countries, whether they are members of the Society or not, then to members of the Society not qualified to apply for conference funds available to university staff. Other members of the Society are also eligible.

Level of Study: Postgraduate

Type: Travel grant

Value: UK£200-300

Length of Study: 1 year, renewals are considered

Frequency: Annual

Country of Study: Any country

Application Procedure: Applicants must contact the Honorary

Secretary for an application form.

Closing Date: January 31st

Funding: Private

No. of awards given last year: 2

Additional Information: Recipients are required to submit a short report on the conference to PAST, the Society's newsletter and their papers for the Society's proceedings if these are not to be included in a conference volume.

\section{Prehistoric Society Conference Fund}

Subjects: Prehistoric archaeology.

Purpose: It's aim is to further the development of prehistory as an international discipline. To offer funding to those who might not otherwise be able to travel to an international conference

Eligibility: There are no eligibility restrictions.

Level of Study: Unrestricted

Type: Scholarship

Value: $£ 200-300$

Frequency: Annual

No. of awards offered: 2 
Application Procedure: Applications from both members and nonmembers will be considered. Applications may also be made by conference organisers, on behalf of attending scholars. Please check website for application: http://www.prehistoricsociety.org/grants/ conference_fund/

Closing Date: January 31 st

Funding: Private

\section{Prehistoric Society Research Fund}

Subjects: Prehistoric archaeology.

Purpose: To further research in prehistory by excavation or other means.

Eligibility: Open to all members of the Society. The Society may make specific conditions relating to individual applications.

Level of Study: Unrestricted

Type: Grant

Value: $£ 100-1,000$

Length of Study: 1 year, renewals are considered

Frequency: Annual

Country of Study: Any country

No. of awards offered: Varies

Application Procedure: Applicants must complete an application

form and include the names of two referees in their application.

Closing Date: January 31st

Funding: Private

Additional Information: Awards are made on the understanding that a detailed report will be made to the Society as to how the grant was spent.

\section{THE PRESIDENT'S COMMISSION ON WHITE HOUSE FELLOWSHIPS}

c/o O.P.M-Sheila Coates, 1900 E.Street, NW, Room B431,

Washington, DC, 20415, United States of America

Tel: (1) 2023954522

Fax: (1) 2023956179

Email: comments@whitehouse.gov

Website: www.whitehouse.gov/fellows

Contact: White House Fellowships

To maintain the healthy functioning of our system it is essential that we have a generous supply of leaders who have an understanding, gained first hand, of the challenges that our national government faces.

\section{White House Fellowships}

Subjects: Domestic and international policy studies.

Purpose: To offer exceptional young men and women first-handed experience working at the highest levels of the federal government. Eligibility: Civilian employees of the Federal government are not eligible.

Level of Study: Postgraduate

Type: Fellowship

Value: A full-time, paid assistantship to the Vice President, Cabinet Securities, and other top-ranking government officials

Length of Study: 1 year

Frequency: Annual

Study Establishment: The White House

Country of Study: United States of America

Application Procedure: Application instructions are available on the website.

Closing Date: February 1st

Additional Information: Please check website for more details.

\section{PRESS GANEY ASSOCIATES INC.}

404 Columbia Place, South Bend, IN, 46601, United States of America

Tel: (1) 8002328032

Fax: (1) 5742464913

Email: info@pressganey.com

Website: www.pressganey.com

Contact: Ms Kelly Leddy, Research Specialist
The Press Ganey Associates, Inc. is the healthcare industry's top satisfaction measurement and improvement firm, serving more than 5,900 healthcare facilities and processing nearly 7,000,000 surveys annually. As one of the industry's market leaders, the company offers one of the world's largest comparative databases and unparalleled benchmarking opportunities.

\section{Press Ganey Best Place to Practice Award}

Subjects: The subject of the grant is patient satisfaction in all aspects of the healthcare industry.

Purpose: To increase the systematic and rigorous study of patient satisfaction, through the funding of applied research that will identify best practices and that can be used throughout the healthcare industry. Eligibility: There are no eligibility restrictions.

Level of Study: Research, Unrestricted

Value: US $\$ 10,000$

Frequency: Annual

No. of awards offered: 5

Application Procedure: Applicants must visit the website or email Kelly Leddy at kleddy@pressganey.com for application procedures. Closing Date: March 14th

Contributor: Press Ganey Associates

No. of awards given last year: 2

No. of applicants last year: 28

\section{PRIMATE CONSERVATION INC.}

1411 Shannock Road, Charlestown, RI, 02813-3726, United States of America Tel: (1) 4013647140

Fax: (1) 4013646785

Email: nrowe@primate.org

Website: www.primate.org

Contact: Noel Rowe, Director

Primate Conservation Inc. gives small grants and matching funds for the conservation projects and studies of the least known and most endangered primates in their natural habitat.

\section{Primate Conservation Inc. Grants}

Subjects: Conservation and research projects on the least known and/or most endangered primates in habitat countries with wild populations.

Purpose: To protect and study the least known and/or most endangered primates in their natural habitats.

Eligibility: Applicants must be graduate students, qualified conservationists or primatologists.

Level of Study: Graduate, Postgraduate, Doctorate, Research

Type: Grant

Value: Average US $\$ 2,500$ maximum $\$ 5,000$

Length of Study: 2 months to 2 years

Frequency: Biannual

No. of awards offered: Varies with each funding season

Application Procedure: Applicants must submit a grant proposal on forms that can be downloaded from the website, and submit three copies of the application to the institution's main address. Proposal must be typed, double spaced and in English. One copy of the proposal should be emailed to nrowe@primate.org.

Closing Date: September 20th and February 1st

Funding: Private

Contributor: Private donation

No. of awards given last year: 20

No. of applicants last year: 55

\section{THE PRIME MINISTER'S RESEARCH FELLOWSHIP}

Indian Institute of Technology Hyderabad, Kandi, Sangareddy, Telangana, 502285, India

Contact: The Prime Minister's Research Fellowship

The Government of India is offering Prime Minister's Research Fellowship Scheme for Doctoral Studies (PhD) in IITs and IISc aimed at attracting the best talent. 


\section{Prime Minister's Research Fellowship Scheme}

Subjects: Scholarships are awarded to study the subjects offered by the university.

Purpose: The Prime Minister's Research Fellowship (PMRF) scheme is aimed at attracting the talent pool of the country to doctoral $(\mathrm{PhD})$ programmes of Indian Institutes of Technology (IITs) and Indian Institute of Science (IISc) for carrying out research in cutting-edge science and technology domains, with focus on national priorities. Eligibility: Citizens of India are eligible to apply. The candidate should have a very good command of English language.

Level of Study: Doctorate

Value: Applicants who fulfill the eligibility criteria, and are finally selected through a selection process, will be offered admission to $\mathrm{PhD}$ program in one of IITs/IISc with a fellowship of Rs. 70,000 per month for the first two years, Rs.75, 000 per month for the 3rd year, and Rs. 80,000 per month in the 4th and 5th years. Apart from this, a research grant of Rs. 2.00 lakh per year will be provided to each of the Fellows for a period of 5 years to cover their academic contingency expenses and for foreign/national travel expenses.

Study Establishment: Scholarships are awarded to study the subjects offered by the university

No. of awards offered: Not known

Application Procedure: The mode of applying is online.

Closing Date: March 31st

Additional Information: For more details please visit to the website http://scholarship-positions.com/prime-minister-research-fellowship/ 2018/02/27/.

\section{PRINCE CHARLES HOSPITAL FOUNDATION'S}

\section{Rode Road, Chermside West, QLD 4032, Australia \\ Contact: Prince Charles Hospital Foundation's}

The Prince Charles Hospital is a major teaching hospital in Brisbane's northside with an emphasis in cardiac and respiratory medicine and cardiothoracic surgery. It also has geriatric and rehabilitation services, elective orthopaedic services and cardiothoracic services, an inpatient psychiatric unit and a 16-bed palliative care unit.

\section{Prince Charles Hospital Foundation's PhD Scholarship}

Subjects: Scholarship is awarded to support educational academic research and high-quality research training at $\mathrm{TPCH}$.

Purpose: The aim of the scholarship is to support educational academic research and high-quality research training at $\mathrm{TPCH}$ or in the significant partnership with TPCH and its associated community programmes. Eligibility: Applicants from Australia are eligible to apply for the scholarship. Applicants must be enrolled, or soon to be enrolled, fulltime in a PhD program at an Australian University.

Level of Study: Doctorate

Value: The scholarship will be valued at $\$ 27,082$ per annum (2018 stipend rate). The scholarship provides the applicant with a living stipend to undertake research at or insignificant association with the Prince Charles Hospital.

Study Establishment: Scholarship is awarded to support educational academic research and high-quality research training at $\mathrm{TPCH}$. Country of Study: Australia

No. of awards offered: Not known

Application Procedure: See the website.

Closing Date: January 23rd

Additional Information: For more details please visit the website http://scholarship-positions.com/prince-charles-hospital-foundationsphd-scholarship-australia/2018/01/09/.

\section{PRINCIPALITY OF LIECHTENSTEIN STATE EDUCATIONAL SUPPORT}

PO Box 684, Principality of Liechtenstein, Vaduz, 9490, Switzerland Tel: (41) 2367681

Email: info@liechtenstein.li

Website: www.liechtenstein.li

The State provides educational assistance in the form of scholarships, loan, or contributions to expenses. Eligibility is determined on the basis of citizenship and the type of education.

\section{Liechtenstein Scholarships and Loans}

Subjects: All subjects.

Purpose: To awaken greater understanding of the Liechtenstein State by the domestic and foreign public.

Eligibility: Open to residents of Liechtenstein, expatriates or those whose mother, father, or spouse is a Liechtenstein citizen are eligible. Level of Study: Postgraduate

Type: Scholarship

Frequency: Annual

Study Establishment: Liechtenstein Institute, Liechtenstein Application Procedure: Applicants should first contact their chosen place of study.

Closing Date: No deadline

Funding: Government

Additional Information: All additional loans must be repaid within 6 years of completion of the course of study.

\section{PROSTATE ACTION}

6 Crescent Stables, 139 Upper Richmond Road, London, SW15 2TN, England

Tel: (44) 02087887720

Fax: (44) 02087891331

Email: ann.rolfe@prostateaction.org.uk

Website: www.prostateaction.org.uk

Contact: Rachel Culley, Research Officer

Vision - The eventual defeat of prostate disease. Mission - To beat prostate disease through research and education. Aims - Prostate disease affects one in two men during their lifetime. We are working to help men and their families beat prostate disease now and in the future.

\section{Prostate Action Research Grants}

Subjects: Research into all prostate diseases.

Purpose: To support research into all prostate diseases.

Eligibility: Available to English-speaking nationals of any country, of any mature age, resident in the United Kingdom and wishing to carry out research at a recognized United Kingdom hospital or institution into malignant or benign prostate disease. Bench space in a United Kingdom hospital/institution must be a prior condition for work to be carried out in the United Kingdom.

Level of Study: Research, Professional development

Value: 3 categories - $£ 10,000, £ 25,000$ and $£ 50,000$

Country of Study: United Kingdom

No. of awards offered: Dependent on funds available

Application Procedure: Advertisements appear once a year in The British Journal Of Urology International inviting applicants to describe research projects they wish to undertake and to indicate the level of funding sought. The advertisements explains the application procedure.

Closing Date: Specified in relevant advertisements

Funding: Individuals, trusts

Contributor: Charitable funds raised by Prostate Action

No. of awards given last year: Approx. 10

No. of applicants last year: Approx. 20

\section{Prostate Action Training Grants}

Subjects: Medical training relevant to the treatment of prostate cancer, benign prostatic hyperplasia and prostatitis.

Purpose: To support UK-based medical professionals for training relevant to the treatment of prostate diseases.

Eligibility: Available to English-speaking nationals of any country, of any mature age, resident in the United Kingdom and wishing to carry out training at a recognized United Kingdom or institution relevant to the treatment of malignant or benign prostate disease. A place at a United Kingdom hospital/institution is a prior condition.

Level of Study: Unrestricted

Type: Grant

Value: Up to $£ 50,000$ over a maximum of 2 years

Country of Study: United Kingdom

No. of awards offered: Dependent on the funds available

Application Procedure: Advertisements appear once a year in The British Medical Journal and The British Journal Of Urology International inviting applicants to describe training they wish to undertake 
and to indicate the level of funding sought. These advertisements explain the application procedure.

Closing Date: See website

Funding: Individuals, trusts

Contributor: Charitable funds raised by Prostate Action

No. of awards given last year: Approx. 5

No. of applicants last year: Approx. 5

\section{PULITZER CENTER ON CRISIS REPORTING}

1779 Massachusetts Avenue, Suite \#615, Washington, DC, 20036, United States of America

Tel: (1) 2023320982

Email: info@pulitzercenter.org

Website: www.pulitzercenter.org

Contact: Nathalie Applewhite, Managing Director

The Pulitzer Center on Crisis Reporting, established in 2006, intends to be a leader in sponsoring the independent reporting that media organizations are increasingly less willing to undertake on their own. It works towards raising the standard of coverage of global affairs, and to do so in a way that engages both the broad public and government policy makers.

\section{Pulitzer Center on Crisis Reporting Travel Grants} Subjects: Journalism.

Purpose: To bring up issues that have gone unreported or underreported in the mainstream American media.

Eligibility: Open to all journalists, writers or filmmakers, staff journalists as well as freelancers of any nationality.

Level of Study: Professional development

Type: Travel grant

Value: Most awards fall in the range of $\$ 2,000-10,000$ but depending on project specifics may be as much as $\$ 20,000$

Frequency: Annual

Country of Study: United States of America

Application Procedure: Applicants must submit a proposed project, curriculum vitae, 3 recent writing samples and 3 references.

Closing Date: February 6th
Additional Information: Applications should be submitted by email to info@pulitzercenter.org.

\section{PYMATUNING LABORATORY OF ECOLOGY (PLE)}

Department of Biological Sciences, University of Pittsburgh, 4249 Fifth Avenue, Pittsburgh, PA, 15260, United States of America

Tel: (1) 4126244350

Fax: (1) 4126244759

Website: www.biology.pitt.edu/facilities/pymatuning Contact: Dr Paula Grabowski, Department Chair

The Pymatuning Laboratory of Ecology (PLE) is a superb year-round facility that is part of Pitt's Department of Biology. Located in Northwestern Pennsylvania on the shores of beautiful Pymatuning Lake, PLE is dedicated to serving the academic community and visitors from around the world.

\section{Leasure K. Darbaker Prize in Botany}

Subjects: Botany.

Purpose: To award funds for the pursuit of excellent graduate and recent postdoctoral research in botany.

Eligibility: Applicants must be graduate students, recent $\mathrm{PhDs}$ or senior researchers initiating new research at PLE.

Level of Study: Postdoctorate, Doctorate, Postgraduate

Type: Research grant

Value: US $\$ 500-1,500$

Length of Study: 1 year

Frequency: Annual

Study Establishment: PLE

Country of Study: United States of America

No. of awards offered: $1-3$

Application Procedure: Applicants must request guidelines from the PLE or refer to the website.

Closing Date: February 1st

Funding: Private

No. of awards given last year: 1

No. of applicants last year: 2 